\title{
Bioactive Compounds in Oxidative Stress-Mediated Diseases: Targeting the NRF2/ARE Signaling Pathway and Epigenetic Regulation
}

\author{
Muthu Thiruvengadam ${ }^{1} \oplus$, Baskar Venkidasamy ${ }^{2}$, Umadevi Subramanian ${ }^{3}$, Ramkumar Samynathan ${ }^{4}$, \\ Mohammad Ali Shariati ${ }^{5,6}{ }^{(}$, Maksim Rebezov ${ }^{6,7}\left(\mathbb{D}\right.$, Shabari Girish ${ }^{8}\left({ }^{\circ}\right.$, Sivakumar Thangavel ${ }^{9}$, \\ Anand Raj Dhanapal ${ }^{10}$, Natalya Fedoseeva ${ }^{11}$, Joohyun Lee ${ }^{1, *}$ and Ill-Min Chung ${ }^{1, *}$
}

check for updates

Citation: Thiruvengadam, M.; Venkidasamy, B.; Subramanian, U.; Samynathan, R.; Ali Shariati, M.; Rebezov, M.; Girish, S.; Thangavel, S.; Dhanapal, A.R.; Fedoseeva, N.; et al. Bioactive Compounds in Oxidative Stress-Mediated Diseases: Targeting the NRF2/ARE Signaling Pathway and Epigenetic Regulation. Antioxidants 2021, 10, 1859. https:// doi.org/10.3390/antiox10121859

Academic Editors: Hye-Youn Cho and Steven R. Kleeberger

Received: 20 October 2021

Accepted: 20 November 2021

Published: 23 November 2021

Publisher's Note: MDPI stays neutral with regard to jurisdictional claims in published maps and institutional affiliations.

Copyright: (c) 2021 by the authors. Licensee MDPI, Basel, Switzerland. This article is an open access article distributed under the terms and conditions of the Creative Commons Attribution (CC BY) license (https:/ / creativecommons.org/licenses/by/ $4.0 /)$.
1 Department of Crop Science, College of Sanghuh Life Science, Konkuk University, Seoul 05029, Korea; muthu@konkuk.ac.kr

2 Department of Biotechnology, Sri Shakthi Institute of Engineering and Technology, Coimbatore 641062, Tamil Nadu, India; baskarbt07@gmail.com

3 Translational Research Platform for Veterinary Biologicals, Tamil Nadu Veterinary and Animal Sciences University, Madhavaram Milk Colony, Chennai 600051, Tamil Nadu, India; umadevi.subramanian@gmail.com

4 R\&D Division Alchem Diagnostics, New No. 1/1, Old No. 78, Gokhale Street, Ramnagar, Coimbatore 641009, Tamil Nadu, India; ramkumarsaha18@gmail.com

5 Research Department, K.G. Razumovsky Moscow State University of Technologies and Management, 73 Zemlyanoy Val, 109004 Moscow, Russia; shariatymohammadali@gmail.com

6 School of Agricultural Sciences, Liaocheng University, 34 Wenhua Road, Liaocheng 252000, China; rebezov@ya.ru

7 Department of Scientific Advisers, V. M. Gorbatov Federal Research Center for Food Systems, 26 Talalikhina Str., 109316 Moscow, Russia

8 School of Life Sciences, St. Joseph College (Autonomous), Bengaluru 560027, Karnataka, India; shabarisarav@gmail.com

9 Post Graduate Department of Microbiology, Ayya Nadar Janaki Ammal College, Sivakasi 626124, Tamil Nadu, India; sivasadhana@yahoo.co.in

10 Department of Biotechnology, Karpagam Academy of Higher Education, Coimbatore 641021, Tamil Nadu, India; rajanandvk88d@gmail.com

11 Department of Zootechnii, Production and Processing of Livestock Products, Russian State Agrarian Correspondence University, 50 Shosse Entuziastov, 143907 Balashikha, Russia; nfedoseeva0208@yandex.ru

* Correspondence: edmund@konkuk.ac.kr (J.L.); imcim@konkuk.ac.kr (I.-M.C.); Tel.: +82-24-500-577 (I.-M.C.)

Abstract: Oxidative stress is a pathological condition occurring due to an imbalance between the oxidants and antioxidant defense systems in the body. Nuclear factor E2-related factor 2 (NRF2), encoded by the gene NFE2L2, is the master regulator of phase II antioxidant enzymes that protect against oxidative stress and inflammation. NRF2/ARE signaling has been considered as a promising target against oxidative stress-mediated diseases like diabetes, fibrosis, neurotoxicity, and cancer. The consumption of dietary phytochemicals acts as an effective modulator of NRF2/ARE in various acute and chronic diseases. In the present review, we discussed the role of NRF2 in diabetes, Alzheimer's disease (AD), Parkinson's disease (PD), cancer, and atherosclerosis. Additionally, we discussed the phytochemicals like curcumin, quercetin, resveratrol, epigallocatechin gallate, apigenin, sulforaphane, and ursolic acid that have effectively modified NRF2 signaling and prevented various diseases in both in vitro and in vivo models. Based on the literature, it is clear that dietary phytochemicals can prevent diseases by (1) blocking oxidative stress-inhibiting inflammatory mediators through inhibiting Keap1 or activating Nrf2 expression and its downstream targets in the nucleus, including HO-1, SOD, and CAT; (2) regulating NRF2 signaling by various kinases like GSK3beta, PI3/AKT, and MAPK; and (3) modifying epigenetic modulation, such as methylation, at the NRF2 promoter region; however, further investigation into other upstream signaling molecules like NRF2 and the effect of phytochemicals on them still need to be investigated in the near future.

Keywords: phytochemicals; NRF2; epigenetic modification; oxidative stress; diabetes; cancer 


\section{Introduction}

Reactive oxygen species (ROS) and reactive nitrogen species (RNS) production are essential for maintaining the body homeostasis and play a key role as regulatory mediators necessary for cell-cell communication or triggering certain signaling pathways. However, at an increased concentration of ROS/RNS in the cellular system, they react with protein, lipids, and DNA molecules and cause detrimental effects in living organisms. In normal conditions, the antioxidant systems, such as catalase, superoxide dismutase (SOD), and glutathione, react with deleterious ROS/RNS into less toxic molecules. During pathological conditions, ROS/RNS overproduction exceeds the antioxidant defense system or dysfunction of antioxidants that are essential to neutralize oxidants, resulting in stress conditions known as oxidative stress. Oxidative stress (OS) will develop into chronic inflammation, leading to various diseases, including diabetes, cardiovascular disease, arthritis, cancer, etc. $[1,2]$.

NRF2 is a redox-sensitive transcription factor encoded by the gene NFE2L2 that is also the master regulator of phase II antioxidant enzymes that protect against oxidative stress and inflammation. Under normal conditions, NRF2 is sequestered by Kelch-like erythroid cell-derived protein with $\mathrm{CNC}$ homology $(\mathrm{ECH})$-associated protein 1 (KEAP1) as a complex in the cytoplasm where its level is regulated by ubiquitination and proteasomal degradation. Under stress conditions, the interaction between the NRF2 and KEAP1 complexes is broken down, and NRF2 is accumulated in the cytoplasm and then translocated into the nucleus, where it binds to phase 2 of the antioxidant response element (ARE) and initiates the transcription of antioxidative enzymes, such as SOD, catalase, etc. [3,4]. Studies have shown that NRF2 inhibition enhances oxidative stress and inflammation by decreasing phase II antioxidant enzymes that affect the function of the renal system and contribute to the development of hypertension in male C57BL/6J mice [5]. NRF2 activator dimethyl fumarate (DMF) significantly accelerated diabetic wound healing by ameliorating diabetesmediated oxidative stress in rat macrophage cells incubated with 25-mM glucose [6]. Studies using MCF-7 and SK-BR breast carcinoma cells showed that NRF2 significantly increased the proliferation activity and progression activity of both carcinoma cells and suggested that NRF2 acts as a prognostic factor in breast cancer patients [7].

Phytochemicals such as polyphenols, flavonoids, steroids, organosulfur compounds, and vitamins are plant metabolites that are widely distributed in various parts of plants and essential for plant growth and development. Currently, phytochemicals have been used to prevent and treat various diseases like diabetes, cardiovascular disease, and cancer [8]. Phytochemicals are reported to have antioxidant potential in both in vitro and in vivo studies. Phytochemicals are reported to directly scavenge ROS and enhance the expression of cellular antioxidant enzymes, thus protecting against oxidative stress-mediated cellular injury [9]. Dietary antioxidants have been proven to protect against the progression of diabetes by inhibiting the lipid peroxidation process [10]. The exposure of environmental toxicants to Drosophila flies enhanced oxidative stress, leading to neurotoxicity, while the dietary intake of phytochemicals prior to paraquat exposure exhibited neuroprotective and antioxidative potential [11]. Studies have shown that phytochemicals can interact with NRF2 signaling and decrease pathological conditions like neurotoxicity, hepatic injury, etc. The oral administration of curcumin resulted in the accumulation of NRF2 in the cytoplasm and subsequent enhanced nuclear translocation and NRF2, thereby reducing hepatic injury in dimethylnitrosamine (DMN)-induced rats [12]. Naringenin has been well-reported to improve mitochondrial dysfunction and ameliorate oxidative stress in neurons of Sprague-Dawley rats via targeting the NRF2-signaling pathway [13]. In this paper, we will explain the latest update in the research progress on dietary phytochemicals that could effectively target NRF2/ARE signaling under various pathological conditions.

\section{NRF2-Antioxidant Defense System Pathway}

NRF2 is a leucine zipper-type transcription factor belonging to the Cap'n'collar (CNC) family, which is linked with the adaptor protein KEAP1 and remains in the cytoplasm. 
During unstressed conditions, KEAP1 activates the ubiquitination and proteasomal degradation of NRF2, leading to a lower level of NRF2 in the cytoplasm, which has a short half-life that could last only $20 \mathrm{~min}$ under normal conditions. Upon stressful conditions, KEAP1 is exposed to excess ROS and RNS, heavy metals, etc., leading to conformational changes in the structure of KEAP1 and to the release and increased stabilization of NRF2, facilitating the nuclear translocation of NRF2. In the nucleus, it forms a heterodimerization complex with another transcription factor named musculoaponeurotic fibrosarcoma (small Maf). This complex, in turn, binds to ARE in the upstream promoter region and activates the transcription of the target genes, including the antioxidant defense system and phase 2 detoxifying enzymes (Figure 1) [2,14]. Apart from KEAP1, several kinases also target NRF2 expression, including GSK3b, PKC, MAPK, and PERK. Extensive studies on NFE2L2/ARE signaling pathways have shown that NRF2 protects various organs, including the pulmonary, hepatic, neural, and cardiovascular systems. Similar to KEAP1, glycogen synthase kinase (GSK) $3 \beta$ phosphorylates NRF2 and causes the proteasomal degradation of NRF2. Alternatively, TGF- $\beta$-activated kinase (TAK), the mammalian target of rapamycin (mTOR), protein kinase $C(\mathrm{PKC})$, and AMP-activated kinase (AMPK) cause the degradation of Keap1, thereby stabilizing and enhancing NRF2 accumulation in the cytoplasm. NRF2 is positively regulated by three MAP kinases, ERK, JNK, and p38, and the protein kinase (PKR)-like endoplasmic reticulum kinase (PERK) [15]. NRF2/ARE signaling has been considered as a promising target against oxidative stress-mediated diseases like diabetes, fibrosis, neurotoxicity, and cancer [16]. In this review, we will focus on the NRF2/ARE signaling pathway and its role in oxidative stress-mediated diseases.

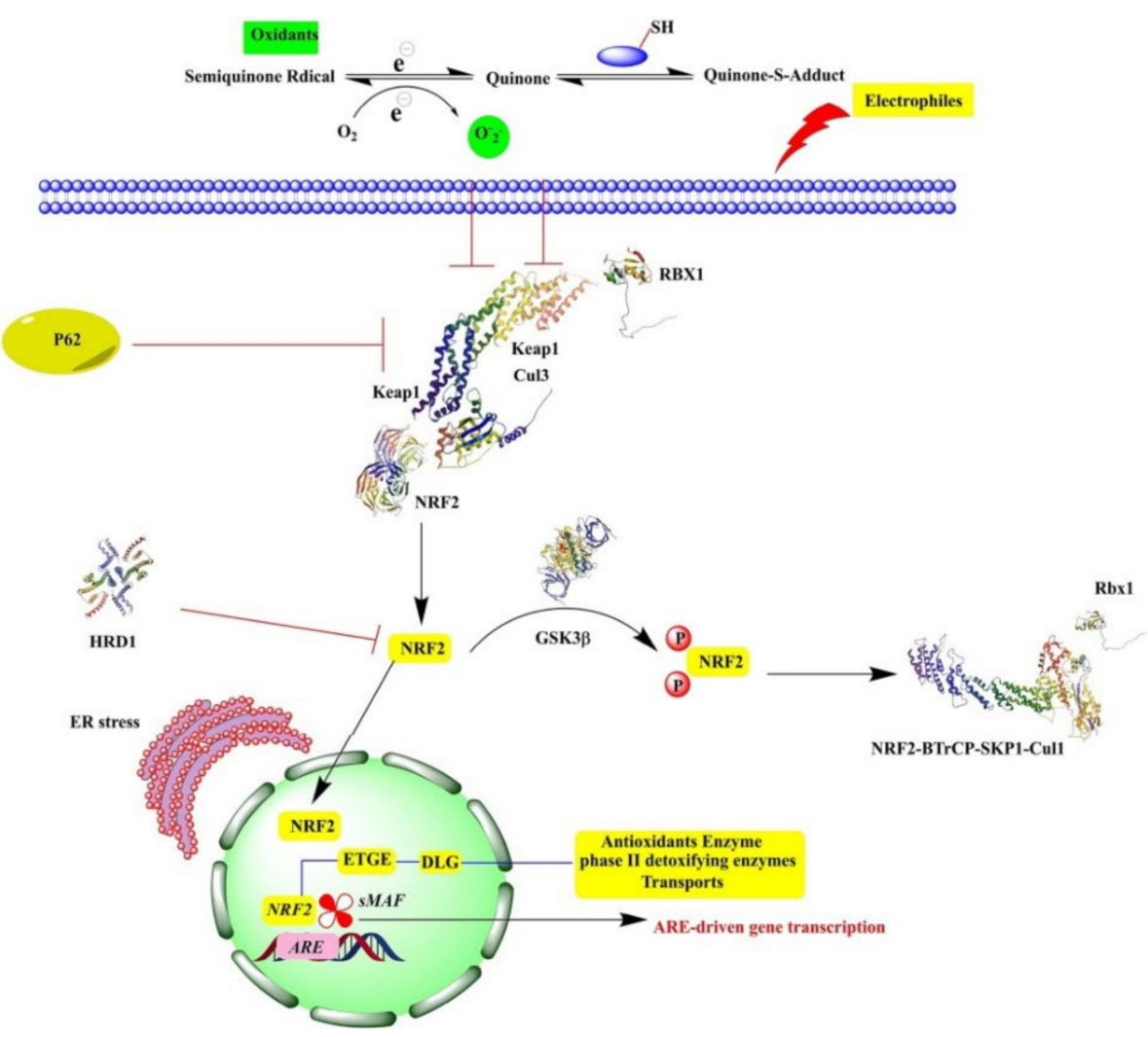

Figure 1. NRF2 activation and nuclear translocation. Cullin3 (Cul3), ring box protein-1 (RBX1), antioxidant response elements (AREs), and the endoplasmic reticulum (ER).

\section{NRF2 Signaling in Oxidative Stress-Mediated Diseases}

Oxidative stress is a pathological condition occurring due to an imbalance between oxidants and antioxidant defense systems in the body. Oxidative stress is linked with the induction of various diseases, both chronic and acute pathologies, the aging process, and 
neurodegeneration. In this section, the role of the NRF2 signaling pathway in various diseases, including diabetes, Alzheimer's disease, kidney injury, and cancer, is discussed (Figure 2).

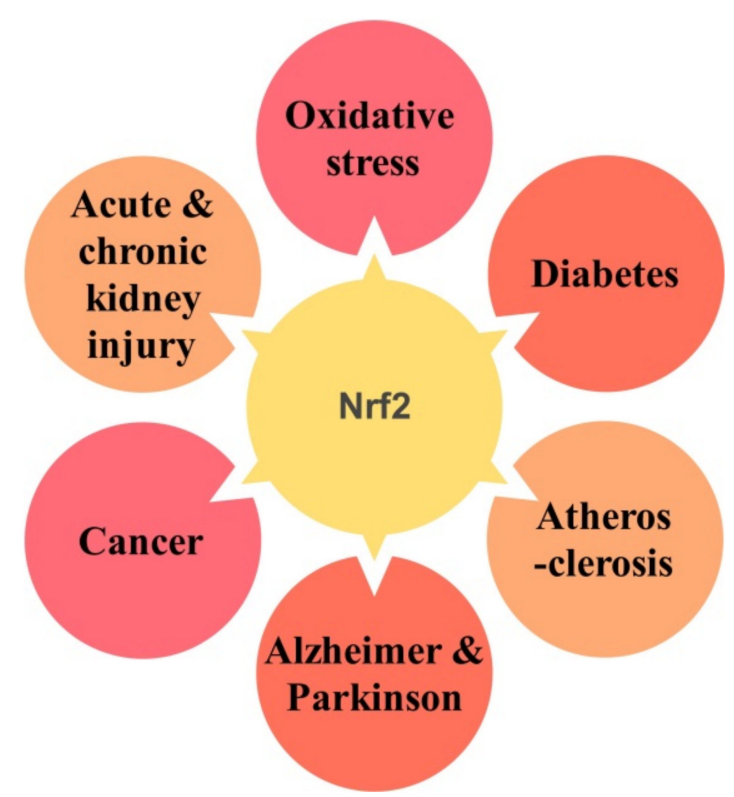

Figure 2. NRF2 signaling pathway is linked with several diseases.

\subsection{Diabetes Mellitus}

In type 2 diabetes mellitus (T2DM), an increased glycemic overload affects the electron transfer with the mitochondrial membrane, causing an accumulation of free radicals and a depletion of antioxidants, leading to oxidative stress [17]. Oxidative stress is a significant factor in the development of vascular problems in diabetes, most notably T2DM. Insulin resistance is an important feature of T2DM but is also necessary for cardiac complications. Studies have shown that extracellular signal-regulated kinase (ERK) is a negative regulator of glucose uptake and mediates oxidative stress-induced insulin resistance. Additionally, ERK signaling is also involved in the suppression of NRF2 activity in cardiac cells, which is linked to oxidative stress-induced insulin resistance [18]. In another study, it was shown that, due to decreased NRF2/ARE activity, oxidative stress and mitochondrial dysfunctions were enhanced, leading to an insulin resistance and endothelial dysfunction observed in diabetes [19]. Interestingly, studies have shown that, in NRF2 knockout mice, insulin secretion from the pancreatic islets is reduced, whereas NRF2 upregulation eventually increases the insulin-secreting potential of pancreatic $\beta$ cells [20]. In streptozotocin (STZ)induced diabetic mice, sulforaphane effectively activated NRF2 expression, leading to the suppression of nephropathy and significantly improving the metabolic parameters such as hyperglycemia, polyuria, polydipsia, and weight loss associated with type II diabetes [21]. In NRF2 knockout mice, the corneal epithelial migration is delayed when compared to that of WT mice, which suggests that NRF2 is mainly responsible for the wound-healing process by promoting cell migration in corneal epithelial cells, and hence, NRF2 might be an attractive therapeutic target of corneal epithelial diseases [22].

\subsection{Atherosclerosis}

Atherosclerosis is a chronic inflammatory disease of large- or medium-sized muscle arteries, while oxidative stress acts mainly as a trigger of atherosclerosis. Due to macrophages' increased production of ROS, circulating LDL is oxidized, resulting in the formation of foam cells and lipid deposition in the arteries, finally resulting in atherosclerotic plaque [23]. To understand the role of NRF2 in atherogenesis, NRF2-deficient ApoE $\mathrm{KO}$ mice $\left(\mathrm{NRF} 2^{-/-} \mathrm{ApoE}^{-/-}\right.$) fed with an atherogenic diet, the data revealed that there 
was decreased hepatic cholesterol and small atherosclerotic plaques developed in the $\mathrm{NRF}^{-/-}, \mathrm{ApoE}^{-/-}$when compared to $\mathrm{NRF}^{+/+}, \mathrm{ApoE}^{-/-}$control mice [24]. In lowdensity lipoprotein (LDL) receptor-deficient mice, NRF2 deficiency in bone marrow-derived cells exacerbates early atherosclerosis. Additionally, the absence of NRF2 results in an increase in the uptake of modified LDL and an increase in the expression of inflammatory markers in thioglycolate-induced peritoneal macrophages, implying that NRF2 has an anti-inflammatory effect in macrophages via increased antioxidant production [25]. In a study, miR-24 expression is decreased in high glucose-induced vascular smooth muscle cells (HG-VSMCs) and, also, in balloon-injured diabetic rats. Upon the deficiency of miR-24, the increased expression of KEAP1 is found together with a decreased expression of NRF2 and heme oxygenase-2 (HO-2) in both HG-VSMCs in diabetic rats. In the same study, the upregulation of miR-24 improved the reendothelialization in balloon-injured diabetic rats, which was due to decreased oxidative stress via the NRF2/HO-1 signaling pathway that restored the activity of antioxidant enzymes SOD and glutathione peroxidize (GPx) in balloon-injured diabetic rats [26].

\subsection{Alzheimer's and Parkinson's Disease}

Oxidative stress has been associated with neurological disorders like multiple sclerosis, Alzheimer's (AD), Parkinson's disease (PD), etc. AD is mainly due to the abnormal deposition of amyloid $\beta$-peptides $(A \beta)$ and accumulation of neurofibrillary tangles containing hyperphosphorylated tau protein and dementia. Studies have shown that oxidative stress increases the aggregation and production of $A \beta$ and, also, stimulates phosphorylation of the tau protein, leading to neurotoxicity. Further, accumulated $A \beta$ and tau protein causes redox imbalance by stimulating dysfunction of the mitochondria, thereby increasing ROS production. Thus, oxidative stress is necessary for the initiation and, also, the progression of AD [27]. Similarly, another study using transgenic mouse models of AD showed that the loss of NRF2 effectively increased the levels of $A \beta$ and phosphorylated tau protein, leading to neurotoxicity [28]. PD is a neurological disorder characterized by the degeneration of dopaminergic neurons in the brain's substantia nigra. It is considered that oxidative stress is a causal factor in dopaminergic neurotoxicity. Evidence shows that dopaminergic neuronal loss in PD is significantly due to ROS production, which results from low GSH, high levels of iron and calcium, and dopamine metabolism [29]. Skibinski et al. suggested that NRF2 decreases the toxicity induced by $\alpha$-synuclein and leucine-rich repeat kinase 2 (LRRK2) by maintaining the neuronal protein homeostasis [30]. Additionally, NRF2 is also involved in the clearance of synuclein and converts the aggregation of LRRK2 into inclusion bodies, leading to decreased neuronal toxicity. In a study, acrylamide was exposed to primary astrocytes and microglia obtained from BALB/c mice and evaluated for neurotoxicity. Acrylamide enhanced the ROS and reduced the antioxidant levels, and additionally, the NRF2 and NF- $\mathrm{kB}$ pathways were also activated. However, NRF2 activity was increased at the earlier stage of acrylamide exposure, leading to neuronal protection. On the other hand, NF- $\mathrm{KB}$ activation occurs at a later stage, leading to the release of proinflammatory mediators like IL-6, TNF- $\alpha$, and IL-1 $\beta$, leading to neurotoxicity [31]. Melatonin is a well-known endogenous antioxidant reported to possess neuroprotective effects via the NRF2-signaling pathway and attenuate neuronal apoptosis in HT22 cells [32].

\subsection{Cancer}

Damage to macromolecules such as protein, DNA, RNA, and membrane lipids occurs as a result of oxidative stress, initiating carcinogenesis. Cancer is a genetic disease in which cells grow out of control and is a multistage process, including initiation, promotion, and progression. Cancer is initiated by ROS-mediated DNA damage, causing gene mutations, genome instability, and altering the DNA structure. In the promotion stage, there will be increased cancer cell proliferation and decreased apoptosis due to abnormal gene expression, improper cell-to-cell communication, and alterations in the second messenger system. In the final stage, oxidative stress involves further DNA alterations and leads 
to the progression stage of cancer [33]. Additionally, oxidative stress together with inflammatory pathways leads to the transformation of a normal cell into a cancerous cell and further enhances cancer cell survival, proliferation, metastasis, chemoresistance, and radioresistance [33]. NRF2 is a potent transcription activator of genes that are involved in the expression of the antioxidant enzyme system, ubiquitin-proteasome system, antiinflammatory response, and xenobiotic metabolism. NRF2 activation is beneficial for a host of cells against oxidative stress-related diseases, including cancer. Many cancers exhibit prolonged NRF2 activation due to genetic mutations and promote malignant growth [34]. Accumulating evidence shows that NRF2 signaling pathways are involved in various cancers and are necessary for tumor invasion, metastasis, resistance to apoptosis, and chemoresistance [35]. Activation of the NRF2-ARE pathway is found in the MCF7 breast cancer cell line and is necessary for chemoresistance under hypoxia through the ROSNRF2-GCLC-GSH pathway [36]. Thus, developing an understanding of the importance of the NRF2-ARE pathway in cancer is an urgent need, and the development of NRF2 inhibitors would provide an opportunity for targeting chemoresistance or development chemotherapy (Figure 3).

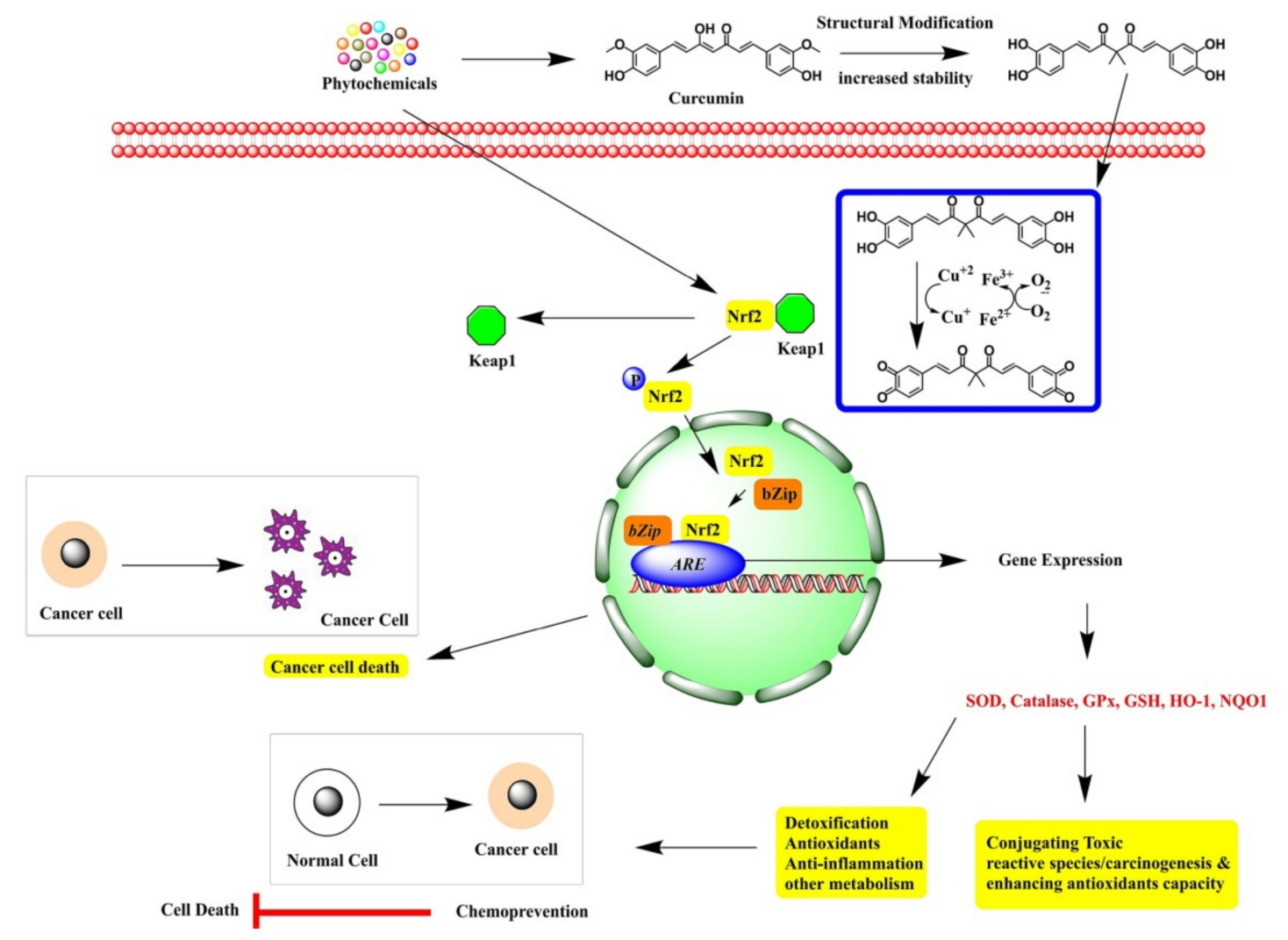

Figure 3. The effects of bioactive compounds in the activation of NRF2 pathways for cancer prevention.

\subsection{Acute and Chronic Kidney Disease}

Oxidative stress, along with inflammation, is an important factor necessary for the initiation and progression of acute and chronic kidney diseases like diabetic nephropathy, hypertension-associated kidney disease, polycystic disease, and glomerulonephritis. Creactive protein, IL-6, TNF- $\alpha$, and fibrinogen, in combination with oxidative stress, induce apoptosis, necrosis, and fibrosis in kidney tissues, eventually leading to chronic kidney disease. Additionally, dysregulated metabolic products like uric acid are also involved in the stimulation of oxidative stress, which would worsen chronic kidney disease [37]. Normally, NRF2 plays a protective role in inducing the expression of antioxidant enzymes and reducing prooxidants. Moreover, studies using the autosomal dominant polycystic kidney disease (ADPKD) mice model showed that the genetic deletion of NRF2 enhanced ROS gen- 
eration and stimulated cyst growth, and to further confirm that NRF2 was activated using pharmacological inhibitors, the data showed that cyst production and disease progression were slowed down in ADPKD mice [38]. Rush et al. suggested that bardoxolone methyl (BARD) has been used in clinical trials as a pharmacologic NRF2 inducer to treat chronic kidney disease [39]. In another study, Tolvaptan, a vasopressin type 2 receptor antagonist, activated the NRF2/HO-1-signaling pathway through the phosphorylation of PERK in renal cortical collecting duct cell lines and showed that Tolvaptan could be effectively used along with BARD for the treatment of kidney disease [40]. In NRF2-deficient mice when compared to wild-type mice, the severity of acute kidney injury is increased due to decreased renal function, increased expression of tubular injury markers, oxidative stress, endoplasmic reticulum stress, and finally, cell death, suggesting the protective role of NRF2 against kidney injury [41] (Figure 4).

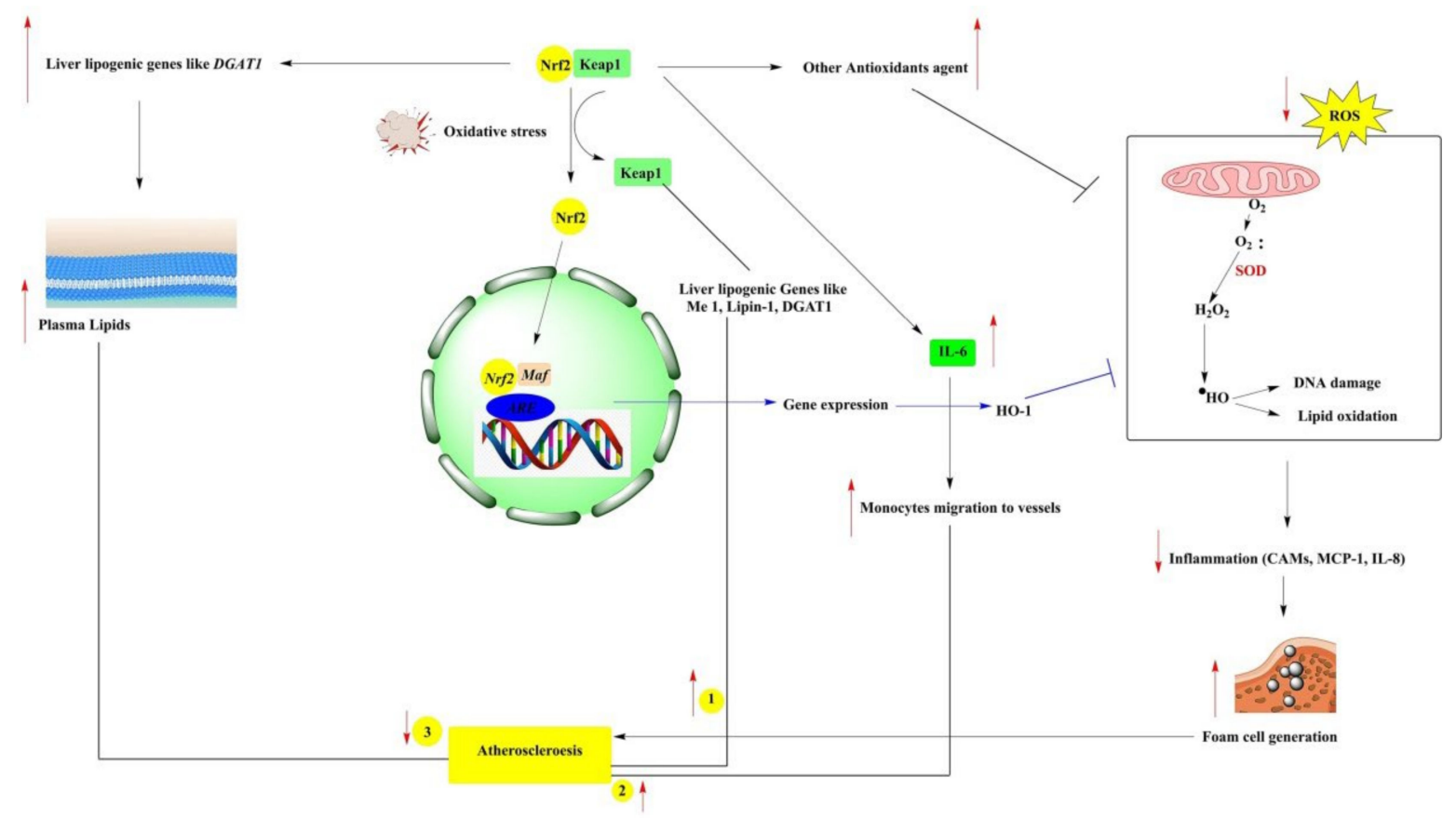

Figure 4. Phytochemicals target NRF2 to inhibit cancer, diabetes, neurotoxicity, cardiac disease, and kidney injury.

\section{Phytochemicals and Regulation of NRF2 Signaling in Various Diseases}

Dietary phytochemicals are widely distributed in fruits, grains, herbs, and vegetables and have been considered to possess various biological properties, like antioxidant, anti-inflammatory, anti-cancerous, antifibrosis, etc. Several studies have shown that the consumption of dietary phytochemicals acts as an effective modulator of NRF2/ARE in various acute and chronic diseases. Additionally, phytochemicals effectively regulate the Nrf2 gene through epigenetic modifications, including histone modifications, miRNA alterations, DNA methylation, etc. In this section, this review provides an update on the role of phytochemicals in regulating NRF2 in various diseases (Figures 4 and 5).

\subsection{Curcumin}

Curcumin is a yellow-colored polyphenol and an active component of the plant Curcuma longa (turmeric). It has been known to possess a wide range of biological activities, such as anti-inflammatory, antioxidant, and ameliorating oxidative stress in C2C12 myoblast cells [42]. Curcumin enhances NRF2 expression and stability and promotes the migration of NRF2 to the nucleus, which, in turn, regulates the expression of antioxidant enzyme heme oxygenase-1 (HO-1) and thereby resists oxidative stress and potentially reduces apoptosis in $\mathrm{H}_{2} \mathrm{O}_{2}$-treated RAW264.7 macrophage cells [43]. In a high-fat diet mice model, curcumin attenuated glucose intolerance by decreasing the oxidative stress 
and improving the nuclear level of NRF2 and its downstream target HO-1 [44]. Due to the anti-inflammatory potential, the curcumin treatment effectively decreased temporomandibular joint (TMJ) osteoarthritis by inhibiting the expression of inflammatory mediators like IL-6, matrix metalloproteinases (MMPs), a disintegrin, and metalloproteinase with a thrombospondin motif (ADAMTS), a collagen. Additionally, it has been reported that curcumin stimulates the NRF2/ARE-signaling pathway in TMJ-induced inflammatory chondrocytes [45]. Interestingly, curcumin analog A13 also mitigates oxidative stress by activating the NRF2/ARE antioxidant defense pathway and subsequently inhibits fibrosis in the myocardium of both high-fat diet and streptozotocin-induced diabetic rats [46]. Curcumin nanoparticles attenuated Huntington's disease via the activation of NRF2 and its downstream targets like antioxidant enzymes (superoxide dismutase) and mitochondrial complexes in rats [47]. In another study, the curcumin analog was shown to inhibit prostate cancer by stimulating NRF2 and its downstream genes via decreasing the expression of Keap1 and, also, decreasing CpG demethylation at the NRF2 promoter by inhibiting DNMT enzymes and HDAC 4 [48]. In rhabdomyolysis-induced acute kidney infection, curcumin, by activating the AMPK, NRF2/HO-1, and PI3K/Akt pathways, effectively inhibited oxidative stress and ameliorated renal injury and apoptosis [49]. Curcumin, at a noncytotoxic concentration, together with cytotoxic 5-fluorouracil, effectively induced apoptosis by decreasing the expression of NRF2 in colorectal cancer cells, which, in turn, suppressed the expression ratio of $\mathrm{Bcl}-2 / \mathrm{Bax}$ and consequently reversed the multidrug resistance of colorectal cancer cells. In cerebral ischemia/reperfusion (I/R) injury, curcumin prevents brain edema and neurological dysfunction by increasing the expression of NRF2 and decreasing the expression of NF- $\mathrm{kB}$ through its antioxidant, antiapoptotic potential [50]. Thus, curcumin can be a potential candidate for inducing NRF2 activation and thereby ameliorating various diseases like diabetes, cerebral injury, cancer, and kidney injury.

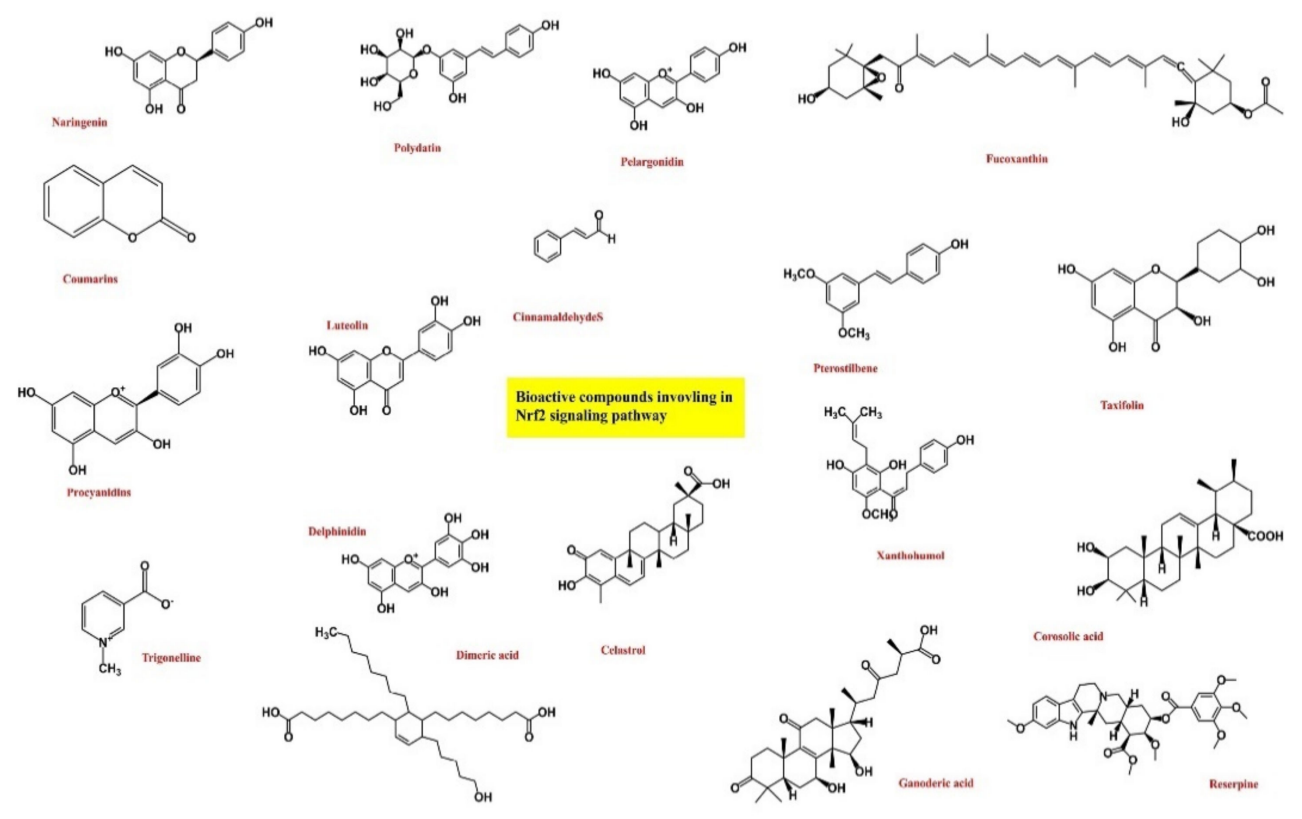

Figure 5. Chemical structure of the bioactive compounds.

\subsection{Quercetin}

Quercetin is the most abundant flavonol and is found in onions, berries, apples, cereals, black and green tea, red grapes, broccoli, cherries, etc. Quercetin has beneficial effects in preventing various diseases, such as lung and cardiovascular diseases and cancer, and also acts neuroprotective, antioxidative, antidiabetic, and hepatoprotective [51]. Quercetin, by increasing the NRF2 mRNA expression, increases the antioxidant defense system and reduces the histological abnormalities and thereby protects Doxorubicin-induced cardiomyopathy in rats [52]. In another study, it was shown that quercetin ameliorates 
oxidative stress-induced ocular disease by upregulating the antioxidant peroxiredoxins by upregulating the NRF2/NRF1 transcription pathway [53]. Quercetin, by inhibiting the ROS/NF-KB/NLRP3 inflammasome/IL-1 $\beta$ and IL-18 pathway and upregulating NRF2 and the anti-inflammatory molecule IL-10, effectively preserves the liver function from alcoholic liver injury [54]. Quercetin exhibited a synergistic effect with sitagliptin and improved cognitive memory by decreasing the $A \beta 1-42$ levels, increasing the expression of NRF2/HO-1, and enhancing the antioxidant activity in the rat brain [55]. Quercetinconjugated superparamagnetic iron oxide nanoparticles (QCSPIONs) decrease $m i R-27 a$ and increase Nrf2 and its responsive genes, including SOD, GPX, and CAT in streptozotocindiabetic rats [56]. In the age-related macular degeneration mice model, the solid dispersion of quercetin significantly reduced the ROS and malondialdehyde content and restored the SOD, catalase, and glutathione peroxidase activities in both the serum and retinal tissues of WT mice when compared to NRF2 KO mice, suggesting that the solid dispersion of quercetin exhibited protective effects by inhibiting retinal oxidative injury through NRF2 activation in mice [57]. In breast cancer cells, quercetin, together with vitamin C, exerted a synergistic effect by decreasing the expression of NRF2 and inducing oxidative stress in the cancer cells. The same study suggested that both compounds can be used as an adjuvant for patients with NRF2-overexpressed cancer [58].

\subsection{Epigallocatechin-3-Gallate (EGCG)}

Epigallocatechin-3-gallate (EGCG) is the main catechin of green tea and is reported to possess antioxidant, anti-inflammatory effects [59]. In diabetic nephropathy (DN), Nrf2 expression is enhanced to counteract oxidative stress. However, NRF2 is not translocated into the nucleus, showing a functional impairment of NRF2. Surprisingly, EGCG acts as a booster in translocating NRF2 into the nucleus and activates the NRF2/ARE pathway, which downregulates KEAP1 and its interaction with NRF2, thereby mitigating DN [60]. In another study, EGCG prevents kidney injury by activating NRF2, inhibiting NAPL3 inflammasome and increasing Treg in lupus nephritis-prone mice, suggesting the antioxidant and anti-inflammatory potential of EGCG [59]. The neurological score showed that EGCG exerted neuroprotective effects by improving cerebral functions, attenuating ROS generation, and by activating the NRF2/ARE signaling pathway and its downstream target genes, such as glutamate-cysteine ligase modulatory subunit and glutamate-cysteine ligase regulatory subunit in the middle cerebral artery occlusion rat model of cerebral I/R injury [61]. EGCG exhibits anticancer activity by maintaining an optimum level of NRF2 to overcome the etoposide resistance in lung cancer cells by using various mechanisms: (1) by activating NRF2 in NCIH23 cells and (2) by controlling the Nrf2 expression via KEAP1dependent and -independent mechanisms (e.g., the p53/p21 and RAR-RXR pathways) in two adenocarcinoma cells [62]. EGCG effectively inhibited intracellular oxidative stress through the activation of NRF2 signaling and also enhanced the level of the antioxidant enzyme, catalase, in renal tubular cells. The knockdown of NRF2 using siRNA inhibited the protective effects of EGCG, suggesting that EGCG offers protection against oxalate-induced EMT via the NRF2 signaling pathway, and it can be used as an effective treatment strategy against renal fibrosis in the near future [62].

\subsection{Resveratrol}

Resveratrol is a natural polyphenolic compound present in berries, grapes, peanuts, and food products such as red wine, and it possesses various biological properties, including antioxidant, anti-inflammatory, and antiplatelet aggregation potential. Resveratrol inhibits diabetes-related cardiac dysfunction and hypertrophy in multiple low doses of streptozotocin-induced diabetic mice by restoring NRF2 and its downstream antioxidative genes, such as SOD, heme oxygenase-1 (HO-1), and metallothionein (MT) [63]. Resveratrol exerts a neuroprotective effect by activating the PI3K/AKT/NRF2 intracellular-signaling pathway and upregulating $\mathrm{HO}-1$ expression in amyloid-beta $\mathrm{A} \beta 1-42$ cytotoxicity-induced PC12 cells [64]. In rotenone-exposed rats, resveratrol downregulated the C/EBP homolo- 
gous protein (CHOP) and glucose-regulated protein 78, decreased the caspase-3 activity, suppressed the xanthine oxidase activity, and activated the NRF2-signaling pathway in the brain and could thereby be developed as a neuroprotective therapeutic agent for Parkinson's disease patients [65]. Resveratrol inhibited the proliferation of pancreatic cancer cells and enhanced apoptosis through ROS accumulation. ROS production by resveratrol activated NRF2 and simultaneously inhibited NAF-1. In the same study, it was reported that resveratrol enhanced the sensitivity of gemcitabine via the ROS/NRF2 intracellularsignaling pathway in pancreatic cancer cells [66]. In a mouse model of age-related renal injury, SIRT1/AMPK and PPAR $\alpha$ signaling were downregulated, while resveratrol improved the renal function, proteinuria, and glomerulosclerosis by activating NRF2 signaling and activating SIRT1/AMPK and PPAR $\alpha$ signaling in the kidney [67]. In high-fat diet (HFD) rats, resveratrol attenuated methylation at the NRF2 promoter region in the liver of mice, which, in turn, reduced lipogenesis by decreasing the expression of genes such as fatty acid synthase and Sterol regulatory element-binding protein (SREBP)-1, suggesting that resveratrol could decrease HG-induced reactive oxygen species production via the NRF2/ARE-signaling pathway [68].

\subsection{Sulforaphane}

Sulforaphane is an isothiocyanate that is found abundantly in cruciferous vegetables such as cabbage, broccoli, and radishes. It showed many biological activities, such as antioxidant, anti-inflammatory, and antitumor activities [69]. In vivo studies using STZinduced Male Sprague-Dawley rats and in vitro studies using high glucose-induced Müller cells showed that sulforaphane effectively decreased the inflammation and improved the antioxidant enzymes in the injured diabetic retina. Furthermore, sulforaphane inhibited the NLRP3 inflammasome and prevented the keap1-mediated proteasomal degradation of NRF2 and enhanced the stabilization and nuclear accumulation of NRF2 together with increasing the expression of $\mathrm{HO}-1$ and $\mathrm{NAD}(\mathrm{P}) \mathrm{H}$ : quinone oxidoreductase 1 (NQO1), thereby inhibiting diabetic retinopathy [70]. Oxidative stress plays a vital role in the pathogenesis of contrast-induced retinopathy (CIN), while sulforaphane effectively attenuates CIN using both in vitro and in vivo experiments via activating the NRF2 antioxidant defense pathway [71]. $\beta$-site APP-cleaving enzyme 1 (BACE1) is the only $\beta$-secretase rate-limiting enzyme necessary for the production and accumulation of amyloid- $\beta$ peptides $(A \beta)$, which is a crucial event involved in the pathogenesis of AD. Studies showed sulforaphane being an effective NRF2 inducer effectively downregulating BACE1 enzymes via upregulating NRF2 target genes, including $\mathrm{HO}-1$, and ameliorating cognitive deficits and preventing accumulation in AD-induced mice models [72]. In an in vivo Parkinson's disease (PD) model using rotenone-mediated neurotoxicity, studies showed that sulforaphane treatment significantly modulated mTOR-mediated p70S6K and 4E-BP1-signaling pathways, inhibited neuronal apoptosis, stimulated the NRF2-dependent reduction of oxidative stress, and ultimately, was involved in the restoration of autophagy, thereby exhibiting the role of sulforaphane as a neuroprotective agent in the PD model [73]. Sulforaphane prevented Ang II-induced cardiomyopathy by activating Akt, which, in turn, inhibits the necessary proteasomal degradation of NRF2. Thus, by activating the AKT/GSK-3 $\beta$ /Fyn pathway, sulforaphane effectively upregulates and activates NRF2 and prevents cardiomyopathy [74].

\subsection{Apigenin}

Apigenin is a naturally occurring plant flavone found richly in fruits and vegetables, including oranges, parsley, celery, etc. It has a variety of biological properties, including the ability to induce apoptosis; prevent DNA damage; and exert immunomodulatory, antioxidant, and anti-inflammatory effects [75]. In high fructose-feeding diet mice, apigenin inhibits the binding of KEAP1 with NRF2, enhances the accumulation and nuclear translocation of NRF2 and its downstream targets $\mathrm{HO}-1$ and NQO1, and ultimately prevents metabolic syndrome [76]. In streptozotocin-induced rats, apigenin-solid lipid nanoparticles effectively prevent diabetic nephropathy by inhibiting the release of inflammatory 
molecules and reducing the lipid peroxidation process through the NRF2/HO-1/NFkB-signaling pathway [77]. In LPS-treated BV2 microglial cells, apigenin attenuated TNF- $\alpha$, IL- $1 \beta$, and IL- 6 production by activating GSK3 $\beta /$ NRF2, suggested to be effective as a therapeutic agent against neurodegenerative diseases [78]. Apigenin acts as a potential chemosensitizer for hepatocellular carcinoma by enabling the sensitization of doxorubicin-treated BEL-7402 cells through the miR101/NRF2-related apoptotic pathway [79]. PI3K/Akt is necessary for glucose uptake and cell survival, and the activation of the PI3K/Akt pathway effectively prevents the development of diabetic neuropathy. In a study, apigenin has been described to activate the PI3K/Akt/NRF2 pathway and improve cell viability in high glucose-treated renal tubular epithelial cells [80]. Apigenin and luteolin at their noncytotoxic concentrations activate the PI3K/NRF2/ARE intracellular pathway system and suppress LPS-induced NO, iNOS, and cPLA2 in human hepatoma HepG2 cells, thereby exerting anti-inflammatory potential [81]. A highly soluble apigenin derivative 6"-O-succinylapigenin showed both neuroprotective and anti-ischemic effects by regulating the ERK/NRF2/HO-1 pathway in a middle cerebral artery occlusion model of male rats [80].

\subsection{Ursolic Acid}

Ursolic acid is a natural pentacyclic triterpenoid acid and is one of the major components present in apples, basil, berries, and fruit peels and is also found in certain medicinal plants. It shows a wide range of biological properties, including antioxidant, anticancer, and anti-inflammatory activities [82]. In middle cerebral artery occlusion mice and NRF2deficient mice, the inflammatory proteins TLR4 and NF-kB are increased, while the pharmacological activation of NRF2 using ursolic acid effectively decreases the TLR4 and NF-kB pathway in MCAO-treated rats, suggesting the anti-inflammatory role of ursolic acid in cerebral ischemia [83]. Ursolic acid effectively enhanced the expression of Nrf2 via the expression of its upstream factor AKT, while, in the $\mathrm{NRF}^{(-/-)}$group, ursolic acid inhibited its neuroprotective effect in a traumatic brain injury mice model [84]. In another study, ursolic acid effectively decreased the oxidative stress in osteoblasts via the IER3/Nrf2-signaling pathway [85]. The ursolic acid sensitizing potential is reduced in NRF2 siRNA-transfected HepG2/DDP cells, and the data showed that ursolic acid possesses a sensitizing potential that is mediated via the NRF2/antioxidant response element-signaling pathway [34]. In CCL4-induced liver fibrosis mice, ursolic acid decreased inflammatory markers such as TNF- $\alpha$, prostaglandin E2, and inducible nitric oxide synthase (iNOS); decreased apoptotic markers like caspase-3; and ultimately, ursolic acid exhibited a hepatoprotective effect against liver fibrosis via the NRF2 / ARE-dependent-signaling pathway [86]. In a skin carcinogenesis study, the expression of $\mathrm{Nrf2}$ and its target gene HO-1 is reduced in skin tumors. Upon ursolic acid treatment, Nrf2 expression is restored by decreasing hypermethylated CpG islands of the Nrf2 gene promoter region in mouse epidermal cells by reducing the expression of epigenetic-modifying enzymes, including the DNA methyltransferases [87].

\subsection{Naringenin}

Naringenin is a bioactive flavonoid found widely in citrus fruits like oranges, grapes, lemons, and tomatoes and is reported to be a well-known antioxidant, anti-inflammatory, and anticancer agent. In a study, naringenin has been reported to possess antidiabetic properties by inhibiting gluconeogenesis, stimulating glycolysis, restoring the insulin levels, and inhibiting apoptosis in both STZ-induced mouse insulinoma cell lines and, also, albino Swiss mice. One of the important mechanisms for the antidiabetic effect of naringenin is by promoting the dissociation of KEAP1 and NRF2 and elevating the antioxidant enzymes like GST in a dose-dependent manner, thereby protecting pancreatic beta cells [88]. Upon exposing mice to an environmental contaminant, perfluorooctane sulfonate, there is an increase in oxidative stress markers like malondialdehyde, hydrogen peroxide, elevated inflammatory mediators like cytokines and interleukins, and stimulated apoptosis, leading to hepatic injury. However, naringenin treatment increased the expression of the NRF2 pro- 
tein and its target genes $H O 1, S O D$, and $C A T$ and decreased the inflammation and inhibited apoptosis via Bax and caspase-3 in the liver tissue of perfluorooctane sulfonate-exposed mice [89]. Naringenin exerts a neuroprotective effect by mitigating oxidative stress and mitochondrial dysfunction by stimulating the Nrf2-signaling pathway and its target genes HO-1 and NQO1 in hypoxia-induced neurons of Sprague-Dawley rats [13]. Controversially, during endometriosis, there is an increased expression of Nrf2 and its target genes HO-1 and NQO1, together with a decrease in the Keap-1 level, while naringenin effectively modulates the NRF2-mediated-signaling pathway and decreases the invasion of endometrial cells and induces apoptosis [90]. In arsenic-induced rats, Nrf-2 and mRNA expression are decreased while naringenin targets the NRF2/HO-1 pathway by its antioxidant and anti-inflammatory potential and thereby decreases myocardial injury [91].

\subsection{Pterostilbene}

Pterostilbene is a natural compound and a demethylated analog of resveratrol found in blueberries and grapes. Pterostilbene prevents several diseases, including aging, cardiovascular disease, diabetes, and cancer [92]. Arsenic induces cytotoxicity and stimulates apoptosis in human keratinocyte cells like HaCaT and JB6 by inhibiting the NRF-signaling pathway. Interestingly, pterostilbene enhanced the accumulation of NRF2 in the cytoplasm and subsequently increased the translocation of NRF2 in the nucleus to express its downstream target genes, inhibiting apoptosis and thereby decreasing the skin damage induced by arsenic [93]. In IL-1 $\beta$-induced chondrocytes, pterostilbene stimulates cytoplasmic stabilization and the nuclear translocation of NRF2 and stimulates its downstream target antioxidant genes and inhibits inflammation, which, altogether, leads to the prevention of chondrocyte damage, cartilage degeneration, and inhibits osteoarthritis [94]. Pterostilbene treatment inhibited gluconeogenesis and stimulated glycolysis in STZ-induced diabetic mice and, also, in MIN6 cells by dissociating the NRF2 and KEAP1 complex and activating NRF2 and enhancing the expression of the downstream target genes of Nrf2 [95]. Pterostilbene is reported to enhance endoplasmic reticulum stress by causing an imbalance in the redox homeostasis that leads to DNA fragmentation and apoptosis in HeLa cells. In addition, it is reported that the anticancer effect of pterostilbene is mediated by the NRF2-signaling pathway by enhancing the phosphorylation of NRF2, which is associated with the activation of its downstream target genes GPX, GR, CAT, and NQO1 [96]. In another study, pterostilbene exhibits anticancer effects against cervical cancer by inducing apoptosis, activating the endoplasmic reticulum (ER)/NRF2 pathway, and decreasing the expression of the HPV oncoprotein E6 in cervical cancer cells [97].

\subsection{Rutin}

Rutin is a flavonol predominantly found in buckwheat, mulberry, grapefruit, orange, lemon, and cranberries. Rutin prevents angiogenesis, decreases oxidative stress, decreases cholesterol accumulation, and inhibits inflammation [98]. Rutin potentially upregulated NRF2 and downregulated iNOS in a dose-dependent manner in t-butyl hydroperoxideinduced oxidative stress in human erythrocytes and albino Swiss mice and protects mouse erythrocytes and liver tissue from oxidative stress-mediated toxicity [99]. Rutin, along with ascorbic acid, protects against UV-induced skin damage by effectively decreasing oxidative stress via activating the NRF2/ARE antioxidant pathway in UVB-irradiated human skin fibroblasts [98]. Similarly, rutin in combination with nimesulide was administered for 8 weeks in the STZ model of diabetes in albino Wistar rats. The inflammatory, apoptotic, and oxidative stress markers (caspase 3, TNF-alpha, NF-kB, and MDA) are increased in STZ-induced diabetic rats. Additionally, the NRF2 levels are decreased in diabetic neurons while rutin with nimesulide effectively ameliorates diabetic neuropathy by targeting the NRF-2/HO-1 and NF-kB-signaling pathways [100]. Rutin protects the heart against environmental pollutants such as bisphenol and dibutyl phthalate by decreasing the oxidative stress and inflammation through increasing the expression of NRF2 and decreasing the expression of NF- $\mathrm{KB}$, thus modulating the NRF2/NF- $\mathrm{BB}$-signaling pathway in the hearts of 
rats, and thus, rutin helps in reducing the risk of developing cardiovascular diseases [101]. Among 19 natural compounds extracted from the Ginkgo biloba extracts (GBE), rutin and procyanidin B2 were reported to suppress t-butyl hydroperoxide (t-BHP)-induced oxidative stress in retinal pigment epithelial cells by stimulating Nrf2 expression together with activating Erk1/2 signaling in injured retinal epithelial cells, thus suggesting that rutin can act as a protective agent in inhibiting oxidative stress-mediated retinal diseases [102]. In another study, brain damage is induced by acrylamide and g-radiation (5Gy), and the protective effect of rutin is analyzed by administering $200-\mathrm{mg} / \mathrm{kg} /$ body wt. orally. It was reported that rutin increased the phosphorylation of PI3K, p-AKT, and p-GSK-3 $\beta$ and also upregulated Nrf2 expression, and it was suggested that the PI3K/AKT/GSK$3 \beta / N R F-2$ pathway is involved in the neuroprotective effect of rutin against acrylamide and g-radiation (5Gy)-induced brain damage [103].

\subsection{Cinnamaldehyde}

Cinnamaldehyde, an active component derived from cinnamon, has been described to show diverse biological activities like anticancer, antimicrobial, antidiabetic, and anticoagulant effects [104]. In a study, cinnamon aldehyde inhibited ROS production, decreased type IV collagen and TGF- $\beta 1$, and thereby ameliorated renal dysfunction and improved endothelium-dependent relaxation of the aorta in diabetic mice. Additionally, cinnamaldehyde enhanced the expression of $\mathrm{Nrf} 2$ and its target genes $\mathrm{HO}-1$ and $\mathrm{NQO}-1$ in diabetic mice. However, in Nrf2-downregulated mice, the protective effects of cinnamaldehyde decreased, which suggested the crucial role of NRF2 in cinnamaldehyde-treated mice [105]. In LPSmediated neuroinflammation, trans-cinnamaldehyde showed an anti-inflammatory effect by reducing the IL- $1 \beta$ levels in the hippocampus of mice. Additionally, cinnamaldehyde increased NRF2 nuclear translocation and also increased the nuclear-to-cytoplasmic NRF2 ratio, and ultimately, trans-cinnamaldehyde exhibited antiapoptotic and anti-amyloidogenic effects [104]. In another study, treadmill exercise together with trans-cinnamaldehyde attenuated cognitive dysfunction by decreasing oxidative stress by stimulating the NRF2signaling pathway and its downstream targets $H O-1, N Q O-1$, and SOD in cognitively impaired mice induced by d-galactose and aluminum chloride [106]. In benzo[a]pyrenetreated $\mathrm{HaCaT}$ cells and normal human epidermal keratinocytes, both Cinnamomum cassia extract and its active compound cinnamaldehyde activated the NRF2/HO1 pathway and inhibited aryl hydrocarbon receptor signaling, thereby suggested to exhibit a beneficial effect on oxidative stress-mediated diseases [107]. In human hepatocarcinoma (HepG2) cells, cinnamon aldehyde stimulates the ERK1/2, JNK, and AKT pathways without altering the p38 MAPK pathway and ultimately leads to the enhanced nuclear translocation of NRF2 and its downstream target phase II enzyme expression, suggesting the anticancer potential of cinnamaldehyde [108]. Cinnamaldehyde exerts a protective effect against high glucose-induced cardiomyocyte injury by upregulating Nrf2 and its target genes HO-1, GPX-1, and NQO-1 and inhibiting cardiomyocyte hypertrophy in diabetic mice [109]. Upon the cotreatment of quercetin, cinnamaldehyde, and hirudin in high glucose-treated dorsal root ganglion neural cells, there is an increased activation of $\mathrm{Nrf}-2 / \mathrm{HO}-1$ and downregulation of the NF- $\mathrm{kB}$ pathway and reduced IL- 6 and TNF- $\alpha$ levels in neurons suggesting the neuroprotective effect of three phytochemicals [110]. Cinnamaldehyde is reported to increase the Nrf2 expression and promoted NRF2 nuclear translocation in HUVECs and ultimately suggested that cinnamaldehyde acts as an effective NRF2 activator in high glucose-treated HUVECs [111].

\subsection{Xanthohumol}

Xanthohumol is a significant prenylflavonoid found primarily in hop plants (Humulus lupulus L.) and has been shown to have antioxidant and anti-inflammatory properties [112]. In the human pancreatic cancer cell line (PANC-1), the combined treatment of xanthohumol and phenethyl isothiocyanate (PEITC) inhibits the expression of p65 and also decreases the binding efficiency of NF- $\mathrm{kB}$ p65 with DNA. Additionally, both 
compounds effectively activated Nrf2 expression and its downstream targets GST, NQO1, and SOD and ultimately led to a decreased proliferation of PANC-1 cells, which suggested the anticancer effects of xanthohumol and phenethyl isothiocyanate [113]. In LPS-induced $\mathrm{NRF}^{-1-}$ (knockout) C57BL/ 6 mice, xanthohumol was reported to suppress acute lung injury via inducing the expression of $N r f 2$ through activation of the AMPK/GSK3 $\beta$ pathway and inhibiting the LPS-induced NF-KB-signaling pathway and Txnip/NLRP3 inflammasome [112]. Interestingly, xanthohumol exerts a nephroprotective effect by suppressing the expression of TLR4 and NF- $\mathrm{KB}$ via activating the NRF2/HO-1-signaling pathway and suppressing the NF- $\mathrm{KB}$-signaling pathway in a dose-dependent manner during cisplatininduced nephrotoxicity in C57BL/6 mice [114]. In a study, xanthohumol is reported to exert both chemopreventive effects on normal hepatocytes and be chemotherapeutic in hepatocellular carcinoma cells by activating Nrf2 and its associated gene expression, including phase II enzymes, in normal cells, while, in cancerous cells, xanthohumol exhibits cytotoxic effects. Additionally, xanthohumol also elevated the expression of GST, HO-1, NQO1, and P53 in normal hepatocytes [115]. Xanthohumol decreases the inflammatory mediators NO, IL- $1 \beta$, and TNF- $\alpha$ and prevents the stimulation of NF- $\mathrm{KB}$ signaling in LPS-induced microglial BV2 cells. Additionally, xanthohumol stabilized the cytoplasmic level of NRF2 and stimulated the nuclear translocation of NRF2 to activate the intracellular expression of GSH, HO-1, and NQO1 in LPS-induced BV2 cells, thereby suggesting the protective role of xanthohumol against brain injury induced by LPS [116]. In another study, it was reported that xanthohumol, through its presence of $\alpha, \beta$-unsaturated ketone structure and activating potential of $N r f 2$ expression, effectively protects neuronal cells and is suggested as a potential candidate against neurodegenerative diseases [117]. A mechanistic study revealed that xanthohumol exerts a neuroprotective role by binding covalently to the Cys residue(s) in the cytosolic inhibitory protein Keap1 and thereby breaks the KEAP1-NRF2 complex to prevent the proteasome degradation of Nrf2 and, eventually, release NRF2 in PC12 cells [117].

In this review, we also provided additional information on the role of other phytochemicals (Tables 1-3) against various diseases targeting NRF2, which showed the importance of NRF2 and, also, to understand the effect of phytochemicals on epigenetic modification. Additionally, Table 2 provides the details of activators and inhibitors of NRF2 that are involved in various diseases. Apart from phytochemicals, the molecules mimicking phytochemicals were also entered into a clinical trial for the treatment of various diseases, including brain ischemia, cancer, etc. To enhance the stability of SFN, Evgen Pharma has developed a cyclodextrin formulation (under the phase II clinical trial), SFX-01, for the treatment of subarachnoid hemorrhage [118]. Yagashita et al. [119] also reviewed that four agents: oltipraz, sulforaphane, dimethyl fumarate, and bardoxolone methyl are in a clinical development that targets NRF2 signaling through interactions with cysteine151 in KEAP1 and suggested that Nrf2 targeting gene biomarkers was the only biomarker class to be affected positively by all four agents.

Table 1. Phytochemicals that target the NRF2-signaling pathway in various diseases.

\begin{tabular}{|c|c|c|c|c|c|}
\hline S.No & Phytochemicals & Molecular Target & Cell/Animal Model & Function & Refs \\
\hline 1. & Luteolin & p62/KEAP1/NRF2 & $\begin{array}{c}\text { Adult male } \\
\text { Sprague-Dawley rats }\end{array}$ & Neuroprotection & {$[120]$} \\
\hline 2. & Fucoxanthin & NRF2 signaling pathway & Skin JB6 P+ cells & Anticancer effect & {$[76]$} \\
\hline 3. & Corosolic acid & Nrf2 expression & Swiss albino mice & Antidiabetic & {$[121]$} \\
\hline 4. & Reserpine & $\begin{array}{l}\text { Epigenetic modulation of } \\
\text { Nrf2 expression }\end{array}$ & Skin epidermal JB6 P+ cells & Anticancer & {$[122]$} \\
\hline 5. & Taxifolin & NRF2 signaling pathway & Male Swiss Albino Mice & $\begin{array}{l}\text { Antioxidant and } \\
\text { anti-inflammatory }\end{array}$ & {$[123]$} \\
\hline
\end{tabular}


Table 1. Cont

\begin{tabular}{|c|c|c|c|c|c|}
\hline S.No & Phytochemicals & Molecular Target & Cell/Animal Model & Function & Refs \\
\hline 6. & Ganoderic acid & Nrf2 expression & Lung cancer H460 cells & Anticancer & {$[124]$} \\
\hline 7. & Celastrol & Nrf2 expression & Male Wistar albino rat & Antifibrotic & [125] \\
\hline 8. & Polydatin & $\begin{array}{l}\text { miR-200a to control } \\
\text { KEAP1/NRF2 pathway b }\end{array}$ & BRL-3A cells & $\begin{array}{l}\text { anti-inflammatory and } \\
\text { antihyperlipidemic }\end{array}$ & [126] \\
\hline 9. & Pelargonidin & $\begin{array}{l}\text { NRF2 promoter } \\
\text { demethylation }\end{array}$ & Skin epidermal JB6 P+ cells. & Anticancer & [127] \\
\hline 10. & Delphinidin & $\begin{array}{c}\text { Epigenetic reactivation } \\
\text { of NRF2 }\end{array}$ & Skin epidermal JB6 P+ cells. & Anticancer & [128] \\
\hline
\end{tabular}

Table 2. List of compounds that act as activators and inhibitors of the NRF2-signaling pathway.

\begin{tabular}{|c|c|c|c|c|c|}
\hline S. No & Compounds & Activator/Inhibitor & Cell/Animal Model/ & Mechanism & Refs \\
\hline 1. & Ursodiol & $\begin{array}{l}\text { FDA approved drug } \\
\text { acting as } \\
\text { NRF2 activator }\end{array}$ & $\begin{array}{l}\text { KEAP1- knockdown mice, Nrf2 } \\
\text { gene-null mice }\end{array}$ & $\begin{array}{c}\text { Activate NRF2; induces of Mrp family } \\
\text { members in livers, stimulates } \\
\text { detoxification and antioxidative } \\
\text { stress systems }\end{array}$ & [129] \\
\hline 2. & Dimeric acid & NRF2 activator & Balb/C mice & $\begin{array}{l}\text { Activates NRF2, increases hepatic } \\
\text { glyoxalase and glutathione, reduces } \\
\text { serum and hepatic AGE levels and } \\
\text { suppresses inflammatory in MG } \\
\text { induced diabetic mice }\end{array}$ & [130] \\
\hline 3. & Songorine & NRF2 activator & C57BL/ 6 mice & $\begin{array}{l}\text { Activates NRF2/ARE signaling } \\
\text { cascades to rescue cardiomyocytes } \\
\text { from endotoxin insult and prevents } \\
\text { septic heart injury }\end{array}$ & [131] \\
\hline 4. & Procyanidins & NRF2 inhibitor & A549 cells & $\begin{array}{l}\text { Promotes proteasome-independent } \\
\text { degradation of nuclear NRF2 via } \\
\text { phosphorylating IGF-1 receptor and } \\
\text { activating cysteine proteases }\end{array}$ & [132] \\
\hline 5. & $\begin{array}{l}\text { Compound } \\
\text { KI-696 }\end{array}$ & $\begin{array}{l}\text { KEAP1 Kelch-NRF2 } \\
\text { interactions inhibitor }\end{array}$ & $\begin{array}{l}\text { NHBE cells, Bronchial epithelial } \\
\text { cells from human COPD } \\
\text { patient lung }\end{array}$ & $\begin{array}{l}\text { Nrf2-regulated genes are expressed in } \\
\text { COPD patient-generated bronchial } \\
\text { epithelial cells }\end{array}$ & [133] \\
\hline 6. & $\begin{array}{l}\text { Cyclic peptide } \\
\text { head to tail }\end{array}$ & $\begin{array}{l}\text { KEAP1-NRF2-specific } \\
\text { protein inhibitor }\end{array}$ & $\begin{array}{l}\text { Mouse RAW } 264.7 \text { cells; } \\
\text { HepG2-ARE-C } 8 \text { cells. }\end{array}$ & $\begin{array}{l}\text { Upregulates NRF2-dependent } \\
\text { antioxidant proteins and } \\
\text { enzymesenhance the antioxidant } \\
\text { capacity and inhibit inflammation } \\
\text { factors in LPS-induced macrophage } \\
\text { RAW } 264.7 \text { cells }\end{array}$ & [134] \\
\hline 7. & Coumarins & $\begin{array}{c}\text { Inhibits KEAP1/NRF2 } \\
\text { protein-protein } \\
\text { interactions }\end{array}$ & $\begin{array}{l}\text { Molecular docking } \\
\text { simulation studies }\end{array}$ & $\begin{array}{c}\text { Binds with Keap and activate } \\
\text { NRF2 signaling }\end{array}$ & [135] \\
\hline 8. & $\begin{array}{l}\text { Napyradiomycin } \\
\text { (Compound } \mathbf{1})\end{array}$ & potent NRF2 activator & BV-2 microglial cells & $\begin{array}{l}\text { Exhibits antioxidant and } \\
\text { anti-inflammatory effects }\end{array}$ & [136] \\
\hline 9. & $\begin{array}{l}\text { ML385 } \\
\text { Small molecule } \\
\text { inhibitor }\end{array}$ & NRF2 inhibitor & Tumor xenograft mice & $\begin{array}{l}\text { Improves chemotherapeutic efficacy } \\
\text { by interacting with NRF2 and } \\
\text { inhibiting its transcriptional activity }\end{array}$ & [137] \\
\hline 10. & Trigonelline & NRF2 inhibitor & $\begin{array}{l}\text { Head and neck cancer } \\
\text { cells (HN3R) }\end{array}$ & $\begin{array}{l}\text { Inhibition of the NRF2-ARE } \\
\text { mechanism reverses ferroptosis } \\
\text { resistance in HNSCC cells }\end{array}$ & [138] \\
\hline
\end{tabular}

\section{Epigenetic Regulation of Phytochemicals on the NRF2-Signaling Pathway}

Sulforaphane promoted demethylation at the NRF2 promoter region, which leads to the activation of Nrf2 expression in Caco2 cells, suggesting the chemoprevention potential of sulforaphane in colon cancer [139]. Using in vitro and in vivo acute myeloid leukemia (AML) models, researchers discovered that quercetin induces apoptosis by decreasing the nuclear translocation of NRF2 and its proteasomal degradation, as well as stimulating the downregulation of epigenetic-modifying enzymes HDAC and the upregulation of 
apoptotic-inducing miRNAs, implying that quercetin epigenetically suppresses AML by targeting the NRf2 pathway. In the TPA-induced neoplastic transformation of mouse skin, sulforaphane treatment exhibits the anticancer potential by effectively decreasing the hypermethylation status at the $\mathrm{CpG}$ islands of the Nrf2 gene promoter, leading to increased gene and protein expressions of NRF2 via modulating the protein expression of DNA methyltransferases and histone deacetylases (epigenetic modifying enzymes) [140]. In prostate cancer, NRF2 is epigenetically silenced during the progression of prostate tumorigenesis in mice. However, curcumin administration reversed the methylation status in the CpG promoter region of the Nrf2 gene, leading to the re-expression of Nrf2 and its target gene, NQO-1, and thereby exerting a chemopreventive effect against prostate cancer [141].

In high glucose-treated HepG2 cells, there is an increased methylation status in the promoter region of NRF2, which could be effectively prevented by resveratrol by inhibiting HG-induced ROS production through demethylation of the NRF2/ARE-signaling pathway [68]. DNA methyltransferase (DNMT) and histone deacetylase (HDAC) assays on mouse skin epidermal JB6 $\mathrm{P}^{+}$cells showed that an apigenin dose dependently prevents skin cancer by effectively reversing the hypermethylated status at the promoter region of the NRF2 promoter, thereby enhancing Nrf2 expression and the nuclear translocation of Nrf2 in skin epidermal JB6 $\mathrm{P}^{+}$cells [75]. Resveratrol also inhibited 17ßestradiol-induced breast carcinogenesis by modulating Nrf2 promoter methylation via miR-93 and stimulating the NRF2/ARE-signaling pathway [142]. $\gamma$-tocopherol, a rich mixture of tocopherols, effectively inhibited hypermethylation at the NRF2 promoter in the prostate of transgenic adenocarcinoma of the mouse prostate (TRAMP) cells and mice, leading to the enhanced expression of NRF2, and prevented prostate cancer in the TRAMP model [143]. Luteolin is a dietary flavone reported to induce apoptosis in human colon cancer cells, and additionally, it exhibits demethylation at the NRF2 promoter region and enhances the interaction of NRF2 and p53 that underlies the anticancer effects of luteolin in colon cancer [144]. Natural phytochemicals such as Z-ligustilide and Radix Angelica Sinensis prevent DNA hypermethylation at the NRF2 gene promoter region via suppressing DNA methyltransferase activity, which leads to the re-expression of Nrf2 and its downstream gene targets in TRAMP mice, which underlies the anticancer potential of phytochemicals against prostate cancer [145]. In this section, we have provided details of the phytochemicals that are involved in epigenetic regulation, as shown in Table 3.

Table 3. List of phytochemicals modulating the epigenetic changes involved in pathological conditions.

\begin{tabular}{|c|c|c|c|c|c|}
\hline S. No & Phytochemicals & $\begin{array}{c}\text { Epigenetic Modification and } \\
\text { Mechanism }\end{array}$ & Cell/Animal Model & Function & Refs \\
\hline 1. & Naringenin & $\begin{array}{l}\text { Histone acetylation-dependent } \\
\text { inhibition of thioredoxin-interacting } \\
\text { protein expression; Regulating } \\
\text { AMPK-mediated p300 inactivation }\end{array}$ & $\begin{array}{l}\text { diabetic } \mathrm{db} / \mathrm{db} \text { mouse } \\
\text { and INS-1 pancreatic } \beta \\
\text { cell line }\end{array}$ & $\begin{array}{l}\text { Protects pancreatic beta } \\
\text { cells and inhibit the } \\
\text { progression of type } \\
\text { II diabetes }\end{array}$ & [146] \\
\hline 2. & Pterostilbene & $\begin{array}{l}\text { Apoptosis in cancer cells is } \\
\text { regulated by } \\
\text { theMTA1/HDAC } 1 / \text { NuRD complex }\end{array}$ & SMMC-7721 & $\begin{array}{l}\text { suppressed the growth, and } \\
\text { invasion of } \\
\text { hepatocellular carcinoma }\end{array}$ & [147] \\
\hline 3. & $\begin{array}{l}\text { 3,4-dihydroxytoluene, a } \\
\text { rutin metabolite }\end{array}$ & $\begin{array}{c}\text { Inhibited p300 histone } \\
\text { acetyltransferase activity and } \\
\text { induced hypoacetylation at H3K9, } \\
\text { H3K36, H4K8 and H4K16. } \\
\text { Decreased lipogenesis-related genes } \\
\text { and attenuated lipid synthesis }\end{array}$ & HepG2 cells ob/ob mice & $\begin{array}{l}\text { Suppressed the progression } \\
\text { of nonalcoholic fatty } \\
\text { liver disease }\end{array}$ & [148] \\
\hline 4. & Cinnamaldehyde & $\begin{array}{l}\text { Regulates PERK-CHOP signaling, } \\
\text { Inhibits G9a histone } \\
\text { methyltransferase, Mediates } \\
\text { autophagic cell death }\end{array}$ & Gastric cancer cells & $\begin{array}{l}\text { Induced autophagy-mediated } \\
\text { cell death through ER stress } \\
\text { and enhanced epigenetic } \\
\text { modification in gastric } \\
\text { cancer cells }\end{array}$ & [149] \\
\hline
\end{tabular}


Table 3. Cont.

\begin{tabular}{|c|c|c|c|c|c|}
\hline S. No & Phytochemicals & $\begin{array}{c}\text { Epigenetic Modification and } \\
\text { Mechanism }\end{array}$ & Cell/Animal Model & Function & Refs \\
\hline 5. & Xanthohumol & $\begin{array}{l}\text { Increased the expression } N r f 2, \\
\qquad H M O X 1 \text { and } N Q O 1\end{array}$ & Marc-145 cells. & $\begin{array}{c}\text { Reduces PRRSV-induced } \\
\text { oxidative stress and inhibits } \\
\text { PRRSV growth }\end{array}$ & {$[150]$} \\
\hline 6. & Ganoderic acid & $\begin{array}{c}\text { Increased expression of } P K R, P E R K \text {, } \\
P R D X 3, N R F 2\end{array}$ & $\begin{array}{l}\text { Senescent human } \\
\text { amniotic mesenchymal } \\
\text { stem cell }\end{array}$ & Acts as an anti-aging agent & {$[151]$} \\
\hline 7. & Celastrol & Deregulation of various miRNA & $\begin{array}{l}\text { Hepatocellular } \\
\text { carcinoma }\end{array}$ & $\begin{array}{l}\text { Inhibits the progression of } \\
\text { hepatocellular carcinoma }\end{array}$ & {$[152]$} \\
\hline 8. & Polydatin & $\begin{array}{l}\text { Increases miR200a expression and } \\
\text { regulates KEAP1/NRF2 } \\
\text { signaling pathway }\end{array}$ & HepG2 and BRL-3A cells & $\begin{array}{l}\text { Reduces fructose-induced } \\
\text { liver inflammation and } \\
\text { lipid accumulation }\end{array}$ & {$[127]$} \\
\hline 9. & Pelargonidin & $\begin{array}{c}\text { inhibits DNA recognition and } \\
\text { catalytic binding by DNMT1 } \\
\text { and DNMT3A }\end{array}$ & HT29 cells & $\begin{array}{l}\text { Regulates cell cycle and } \\
\text { inhibits proliferation of } \\
\text { colorectal carcinoma cells }\end{array}$ & [153] \\
\hline 10. & Delphinidin & $\begin{array}{l}\text { Modulate protein expression of } \\
\text { DNMT1, DNMT3a, and class I/II } \\
\text { HDACs activates the } \\
\text { NRF2-ARE pathway }\end{array}$ & $\begin{array}{l}\text { Mouse epidermal JB6 } \\
\text { P+ cells }\end{array}$ & $\begin{array}{l}\text { Inhibits neoplastic } \\
\text { transformation and acts as } \\
\text { an effective skin cancer } \\
\text { chemo preventive agent }\end{array}$ & [129] \\
\hline 11. & Luteolin & $\begin{array}{l}\text { regulates NRF2/ARE pathway via } \\
\text { modulating DNMTs and HDACs }\end{array}$ & $\begin{array}{l}\text { Human colon cancer } \\
\text { cells HCT116 }\end{array}$ & $\begin{array}{l}\text { Exerts anti-tumor activity by } \\
\text { blocking cell transformation }\end{array}$ & [154] \\
\hline 12. & Fucoxanthin & $\begin{array}{l}\text { Activated NRF2 signaling and } \\
\text { reduced DNMT activity }\end{array}$ & $\begin{array}{l}\text { Mouse skin epidermal } \\
\text { JB6 P+ cells }\end{array}$ & $\begin{array}{l}\text { Involves in skin cancer } \\
\text { prevention and inhibits } \\
\text { cell transformation }\end{array}$ & {$[155]$} \\
\hline 13. & Corosolic acid & $\begin{array}{l}\text { Modules global CpG methylation at } \\
\text { tumor promoter }\end{array}$ & $\begin{array}{l}\text { Mouse epidermal JB6 } \\
\text { P+ cells }\end{array}$ & $\begin{array}{l}\text { Acts as an effective agent } \\
\text { against skin cancer }\end{array}$ & {$[156]$} \\
\hline
\end{tabular}

\section{Conclusions}

Oxidative stress and inflammation are the two important factors necessary for the pathogenesis of various diseases, including diabetes, atherosclerosis, kidney injury, AD, $\mathrm{PD}$, cancer, etc. The important mechanism that is necessary for the cellular defense against oxidative stress is the NRF2-signaling pathway. With these concepts, researchers are paying more attention to identifying the agents that could target oxidative stress and inflammation via the NRF2 intracellular-signaling pathway. Among them, phytochemicals are widely used as important therapeutic agents targeting oxidative stress and inflammation. Several lines of evidence support the use of phytochemicals in modulating dysregulated signaling pathways in a variety of disease models. In the present review, we discussed the role of NRF2 during diabetes, AD, PD, cancer, and atherosclerosis. Additionally, we discussed the phytochemicals that have effectively modified NRF2 signaling and prevented various diseases in both in vitro and in vivo models. In this review, we discussed important phytochemicals like curcumin, quercetin, resveratrol, EGCG, apigenin, sulforaphane, and ursolic acid that act as effective NRF2 inducers. Throughout this review, we learned that dietary phytochemicals can prevent diseases by (1) blocking oxidative stress-inhibiting inflammatory mediators through inhibiting Keap1 or activating Nrf2 expression and its downstream targets in the nucleus, including $\mathrm{HO}-1, S O D$, and $C A T$; (2) regulating NRF2 signaling by various kinases-like Gsk3beta, PI3/AKT, and MAPK; and (3) altering epigenetic modulation like methylation at the promoter region of NRF2 is also one of the important targets of phytochemicals in preventing disease. Thus, the above three mechanisms can be targeted for oxidative stress-mediated diseases. We have also discussed the miRNA and HDACs that can modify NRF2 in various disease models. However, further investigation into another upstream signaling, histone methylation enzymes targeting NRF2 and the effect of phytochemicals on them still need to be investigated, which might provide additional targets for the prevention of oxidative stress-mediated diseases. This review clearly demonstrates that NRF2/KEAP1 signaling could be an effective target for various 
pathological conditions, including cancer, Alzheimer's, etc. Phytochemicals are receiving increased attention due to their role as NRF2 activators and inhibitors; however, much research still needs to investigate the understanding that their pharmacokinetic and dynamic profiles and, also, clinical studies need to be conducted using various phytochemicals and its synthetic moieties against various diseases targeting NRF2 signaling.

Author Contributions: M.T., B.V., U.S., I.-M.C. and M.A.S. conceived the review idea and focused and drafted the article. R.S., M.R., S.G., S.T., J.L., A.R.D. and N.F. were involved in the reference collection and writing the article. All authors have read and agreed to the published version of the manuscript.

Funding: This research received no external funding.

Conflicts of Interest: The authors declare no conflict of interest.

\section{References}

1. Ma, Q. Transcriptional responses to oxidative stress: Pathological and toxicological implications. Pharmacol. Ther. 2010, 125, 376-393. [CrossRef] [PubMed]

2. Ma, Q. Role of nrf2 in oxidative stress and toxicity. Annu. Rev. Pharmacol. Toxicol. 2013, 53, 401-426. [CrossRef] [PubMed]

3. Hannan, M.; Dash, R.; Sohag, A.A.M.; Haque, M.; Moon, I.S. Neuroprotection against oxidative stress: Phytochemicals targeting TrkBsignaling and the Nrf2-ARE antioxidant system. Front. Mol. Neurosci. 2020, 13, 116. [CrossRef] [PubMed]

4. Liu, X.F.; Zhou, D.D.; Xie, T.; Malik, T.H.; Lu, C.B.; Li, H.J.; Hao, J.L. Nrf2, a potential therapeutic target against oxidative stress in corneal diseases. Oxid. Med. Cell. Longev. 2017, 2017, 2326178. [CrossRef]

5. Farooqui, Z.; Mohammad, R.S.; Lokhandwala, M.F.; Banday, A.A. Nrf2 inhibition induces oxidative stress, renal inflammation and hypertension in mice. Clin. Exp. Hypertens. 2021, 43, 175-180. [CrossRef]

6. Li, M.; Yu, H.; Pan, H.; Zhou, X.; Ruan, Q.; Kong, D.; Yao, P. Nrf2 suppression delays diabetic wound healing through sustained oxidative stress and inflammation. Front. Pharmacol. 2019, 10, 1099. [CrossRef]

7. Onodera, Y.; Motohashi, H.; Takagi, K.; Miki, Y.; Shibahara, Y.; Watanabe, M.; Suzuki, T. NRF2 immunolocalization in human breast cancer patients as a prognostic factor. Endocr.-Relat. Cancer 2014, 21, 241-252. [CrossRef]

8. Zhang, Y.J.; Gan, R.Y.; Li, S.; Zhou, Y.; Li, A.N.; Xu, D.P.; Li, H.B. Review Antioxidant phytochemical for the prevention and treatment of chronic disease. Molecules 2015, 20, 21138-21156. [CrossRef]

9. Hannan, M.A.; Sohag, A.A.M.; Dash, R.; Haque, M.N.; Mohibbullah, M.; Oktaviani, D.F.; Moon, I.S. Phytosterols of marine algae: Insights into the potential health benefits and molecular pharmacology. Phytomedicine 2020, 69, 153201. [CrossRef]

10. Montonen, J.; Knekt, P.; Järvinen, R.; Reunanen, A. Dietary antioxidant intake and risk of type 2 diabetes. Diabetes Care 2004, 27, 362-366. [CrossRef]

11. Park, J.H.; Jung, J.W.; Ahn, Y.J.; Kwon, H.W. Neuroprotective properties of phytochemicals against paraquat-induced oxidative stress and neurotoxicity in Drosophila melanogaster. Pestic. Biochem. Physiol. 2012, 104, 118-125. [CrossRef]

12. Farombi, E.O.; Shrotriya, S.; Na, H.K.; Kim, S.H.; Surh, Y.J. Curcumin attenuates dimethylnitrosamine-induced liver injury in rats through Nrf2-mediated induction of heme oxygenase-1. Food Chem. Toxicol. 2008, 46, 1279-1287. [CrossRef]

13. Wang, K.; Chen, Z.; Huang, L.; Meng, B.; Zhou, X.; Wen, X.; Ren, D. Naringenin reduces oxidative stress and improves mitochondrial dysfunction via activation of the Nrf2/ARE signaling pathway in neurons. Int. J. Mol. Med. 2017, 40, 1582-1590. [CrossRef]

14. Loboda, A.; Damulewicz, M.; Pyza, E.; Jozkowicz, A.; Dulak, J. Role of Nrf2/HO-1 system in development, oxidative stress response and diseases: An evolutionarily conserved mechanism. Cell. Mol. Life Sci. 2016, 73, 3221-3247. [CrossRef]

15. Matzinger, M.; Fischhuber, K.; Heiss, E.H. Activation of Nrf2 signaling by natural products-can it alleviate diabetes? Biotechnol. Adv. 2018, 36, 1738-1767. [CrossRef]

16. Egbujor, M.C.; Saha, S.; Buttari, B.; Profumo, E.; Saso, L. Activation of Nrf2 signaling pathway by natural and synthetic chalcones: A therapeutic road map for oxidative stress. Expert Rev. Clin. Pharmacol. 2021, 14, 465-480. [CrossRef]

17. Giacco, F.; Brownlee, M. Oxidative stress and diabetic complications. Circ. Res. 2010, 107, 1058-1070. [CrossRef]

18. Tan, Y.; Ichikawa, T.; Li, J.; Si, Q.; Yang, H.; Chen, X.; Cui, T. Diabetic downregulation of Nrf2 activity via ERK contributes to oxidative stress-induced insulin resistance in cardiac cells in vitro and in vivo. Diabetes 2011, 60, 625-633. [CrossRef]

19. Cheng, X.; Siow, R.C.; Mann, G.E. Impaired redox signaling and antioxidant gene expression in endothelial cells in diabetes: A role for mitochondria and the nuclear factor-E2-related factor 2-Kelch-like ECH-associated protein 1 defense pathway. Antioxid. Redox Signal. 2011, 14, 469-487. [CrossRef]

20. Uruno, A.; Furusawa, Y.; Yagishita, Y.; Fukutomi, T.; Muramatsu, H.; Negishi, T.; Yamamoto, M. The Keap1-Nrf2 system prevents onset of diabetes mellitus. Mol. Cell. Biol. 2013, 33, 2996-3010. [CrossRef]

21. Zheng, H.; Whitman, S.A.; Wu, W.; Wondrak, G.T.; Wong, P.K.; Fang, D.; Zhang, D.D. Therapeutic potential of Nrf2 activators in streptozotocin-induced diabetic nephropathy. Diabetes 2011, 60, 3055-3066. [CrossRef] [PubMed]

22. Hayashi, R.; Himori, N.; Taguchi, K.; Ishikawa, Y.; Uesugi, K.; Ito, M.; Nishida, K. The role of the Nrf2-mediated defense system in corneal epithelial wound healing. Free Radic. Biol. Med. 2013, 61, 333-342. [CrossRef] [PubMed] 
23. Mimura, J.; Itoh, K. Role of Nrf2 in the pathogenesis of atherosclerosis. Free Radic. Biol. Med. 2015, 88, 221-232. [CrossRef] [PubMed]

24. Barajas, B.; Che, N.; Yin, F.; Rowshanrad, A.; Orozco, L.D.; Gong, K.W.; Araujo, J.A. NF-E2-related factor 2 promotes atherosclerosis by effects on plasma lipoproteins and cholesterol transport that overshadow antioxidant protection. Arterioscler. Thromb. Vasc. Biol. 2011, 31, 58-66. [CrossRef]

25. Ruotsalainen, A.K.; Inkala, M.; Partanen, M.E.; Lappalainen, J.P.; Kansanen, E.; Mäkinen, P.I.; Levonen, A.L. The absence of macrophage Nrf2 promotes early atherogenesis. Cardiovasc. Res. 2013, 98, 107-115. [CrossRef]

26. Zhang, S.; Xu, S.; Duan, H.; Zhu, Z.; Yang, Z.; Cao, J.; Duan, J. A novel, highly-water-soluble apigenin derivative provides neuroprotection following ischemia in male rats by regulating the ERK/Nrf2/HO-1 pathway. Eur. J. Pharmacol. 2019, 855, 208-215. [CrossRef]

27. Uddin, M.S.; Kabir, M.T. Oxidative stress in Alzheimer's disease: Molecular hallmarks of underlying vulnerability. In Biological, Diagnostic and Therapeutic Advances in Alzheimer's Disease; Springer: Singapore, 2019; pp. 91-115.

28. Branca, C.; Ferreira, E.; Nguyen, T.V.; Doyle, K.; Caccamo, A.; Oddo, S. Genetic reduction of Nrf2 exacerbates cognitive deficits in a mouse model of Alzheimer's disease. Hum. Mol. Genet. 2017, 26, 4823-4835. [CrossRef]

29. Dias, V.; Junn, E.; Mouradian, M.M. The role of oxidative stress in Parkinson's disease. J. Parkinsons Dis. $2013,3,461-491$. [CrossRef]

30. Skibinski, G.; Hwang, V.; Ando, D.M.; Daub, A.; Lee, A.K.; Ravisankar, A.; Finkbeiner, S. Nrf2 mitigates LRRK2-and $\alpha$-synucleininduced neurodegeneration by modulating proteostasis. Proc. Natl. Acad. Sci. USA 2017, 114, 1165-1170. [CrossRef]

31. Zhao, M.; Wang, F.S.L.; Hu, X.; Chen, F.; Chan, H.M. Acrylamide-induced neurotoxicity in primary astrocytes and microglia: Roles of the Nrf2-ARE and NF-kB pathways. Food Chem. Toxicol. 2017, 106, 25-35. [CrossRef]

32. Ali, T.; Rehman, S.U.; Shah, F.A.; Kim, M.O. Acute dose of melatonin via Nrf2 dependently prevents acute ethanol-induced neurotoxicity in the developing rodent brain. J. Neuroinflamm. 2018, 15, 1-19. [CrossRef]

33. Reuter, S.; Gupta, S.C.; Chaturvedi, M.M.; Aggarwal, B.B. Oxidative stress, inflammation, and cancer: How are they linked? Free Radic. Biol. Med. 2010, 49, 1603-1616. [CrossRef]

34. Wu, S.; Zhang, T.; Du, J. Ursolic acid sensitizes cisplatin-resistant HepG2/DDP cells to cisplatin via inhibiting Nrf2/ARE pathway. Drug Des. Develop. Ther. 2016, 10, 3471. [CrossRef]

35. De la Vega, M.R.; Chapman, E.; Zhang, D.D. NRF2 and the hallmarks of cancer. Cancer Cell 2018, 34, 21-43. [CrossRef]

36. Syu, J.P.; Chi, J.T.; Kung, H.N. Nrf2 is the key to chemotherapy resistance in MCF7 breast cancer cells under hypoxia. Oncotarget 2016, 7, 14659. [CrossRef]

37. Gyurászová, M.; Gurecká, R.; Bábíčková, J.; Tóthová, L'. Oxidative stress in the pathophysiology of kidney disease: Implications for noninvasive monitoring and identification of biomarkers. Oxid. Med. Cell. Longev. 2020, 2020, 5478708. [CrossRef]

38. Lu, Y.; Sun, Y.; Liu, Z.; Lu, Y.; Zhu, X.; Lan, B.; Chen, Y. Activation of NRF2 ameliorates oxidative stress and cystogenesis in autosomal dominant polycystic kidney disease. Sci. Transl. Med. 2020, 12, eaba3613. [CrossRef]

39. Rush, B.M.; Bondi, C.D.; Stocker, S.D.; Barry, K.M.; Small, S.A.; Ong, J.; Tan, R.J. Genetic or pharmacologic Nrf2 activation increases proteinuria in chronic kidney disease in mice. Kidney Int. 2021, 99, 102-116. [CrossRef]

40. Fujiki, T.; Ando, F.; Murakami, K.; Isobe, K.; Mori, T.; Susa, K.; Uchida, S. Tolvaptan activates the Nrf2/HO-1 antioxidant pathway through PERK phosphorylation. Sci. Rep. 2019, 9, 9245. [CrossRef]

41. Rubio-Navarro, A.; Vázquez-Carballo, C.; Guerrero-Hue, M.; García-Caballero, C.; Herencia, C.; Gutiérrez, E.; Moreno, J.A. Nrf2 plays a protective role against intravascular hemolysis-mediated acute kidney injury. Front. Pharmacol. 2019, 10, 740. [CrossRef]

42. Lee, D.Y.; Chun, Y.S.; Kim, J.K.; Lee, J.O.; Lee, Y.J.; Ku, S.K.; Shim, S.M. Curcumin ameliorated oxidative stress and inflammationrelated muscle disorders in C2C12 myoblast cells. Antioxidants 2021, 10, 476. [CrossRef] [PubMed]

43. Lin, X.; Bai, D.; Wei, Z.; Zhang, Y.; Huang, Y.; Deng, H.; Huang, X. Curcumin attenuates oxidative stress in RAW264. 7 cells by increasing the activity of antioxidant enzymes and activating the Nrf2-Keap1 pathway. PLoS ONE 2019, 14, e0216711.

44. He, H.J.; Wang, G.Y.; Gao, Y.; Ling, W.H.; Yu, Z.W.; Jin, T.R. Curcumin attenuates Nrf2 signaling defect, oxidative stress in muscle and glucose intolerance in high fat diet-fed mice. World J. Diabetes 2012, 3, 94. [CrossRef] [PubMed]

45. Jiang, C.; Luo, P.; Li, X.; Liu, P.; Li, Y.; Xu, J. Nrf2/ARE is a key pathway for curcumin-mediated protection of TMJ chondrocytes from oxidative stress and inflammation. Cell Stress Chaperones 2020, 25, 395-406. [CrossRef] [PubMed]

46. Xiang, L.; Zhang, Q.; Chi, C.; Wu, G.; Lin, Z.; Li, J.; Chen, G. Curcumin analog A13 alleviates oxidative stress by activating Nrf2/ARE pathway and ameliorates fibrosis in the myocardium of high-fat-diet and streptozotocin-induced diabetic rats. Diabetol. Metab. Syndr. 2020, 12, 1-8. [CrossRef]

47. Sandhir, R.; Yadav, A.; Mehrotra, A.; Sunkaria, A.; Singh, A.; Sharma, S. Curcumin nanoparticles attenuate neurochemical and neurobehavioral deficits in experimental model of Huntington's disease. Neuromol. Med. 2014, 16, 106-118. [CrossRef]

48. Li, C.W.; Chang, P.Y.; Chen, B.S. Investigating the mechanism of hepatocellular carcinoma progression by constructing genetic and epigenetic networks using NGS data identification and big database mining method. Oncotarget 2016, 7, 79453. [CrossRef]

49. Wu, J.; Pan, X.; Fu, H.; Zheng, Y.; Dai, Y.; Yin, Y.; Hou, D. Effect of curcumin on glycerol-induced acute kidney injury in rats. Sci. Rep. 2017, 7, 10114. [CrossRef]

50. Li, W.; Pung, D.; Su, Z.Y.; Guo, Y.; Zhang, C.; Yang, A.Y.; Kong, A.N. Epigenetics reactivation of Nrf2 in prostate TRAMP C1 cells by curcumin analogue FN1. Chem. Res. Toxicol. 2016, 29, 694-703. [CrossRef] 
51. Ganesan, P.; Ko, H.M.; Kim, I.S.; Choi, D.K. Recent trends in the development of nanophytobioactive compounds and delivery systems for their possible role in reducing oxidative stress in Parkinson's disease models. Int. J. Nanomed. 2015, $10,6757$. [CrossRef]

52. Sharma, A.; Parikh, M.; Shah, H.; Gandhi, T. Modulation of Nrf2 by quercetin in doxorubicin-treated rats. Heliyon 2020, 6, e03803. [CrossRef]

53. Miyamoto, N.; Izumi, H.; Miyamoto, R.; Kondo, H.; Tawara, A.; Sasaguri, Y.; Kohno, K. Quercetin induces the expression of peroxiredoxins 3 and 5 via the Nrf2/NRF1 transcription pathway. Investig. Ophthalmol. Vis. Sci. 2011, 52, 1055-1063. [CrossRef]

54. Liu, S.; Tian, L.; Chai, G.; Wen, B.; Wang, B. Targeting heme oxygenase-1 by quercetin ameliorates alcohol-induced acute liver injury via inhibiting NLRP3 inflammasome activation. Food Funct. 2018, 9, 4184-4193. [CrossRef]

55. Li, Y.; Tian, Q.; Li, Z.; Dang, M.; Lin, Y.; Hou, X. Activation of Nrf2 signaling by sitagliptin and quercetin combination against $\beta$-amyloid induced Alzheimer's disease in rats. Drug Dev. Res. 2019, 80, 837-845. [CrossRef]

56. Ebrahimpour, S.; Shahidi, S.B.; Abbasi, M.; Tavakoli, Z.; Esmaeili, A. Quercetin-conjugated superparamagnetic iron oxide nanoparticles (QCSPIONs) increases Nrf2 expression via miR-27a mediation to prevent memory dysfunction in diabetic rats. Sci. Rep. 2020, 10, 15957. [CrossRef]

57. Shao, Y.; Yu, H.; Yang, Y.; Li, M.; Hang, L.; Xu, X. A solid dispersion of quercetin shows enhanced Nrf2 activation and protective effects against oxidative injury in a mouse model of dry age-related macular degeneration. Oxid. Med. Cell. Longev. 2019, 2019, 1479571. [CrossRef]

58. Mostafavi Pour, Z.; Ramezani, F.; Keshavarzi, F.; Samadi, N. The role of quercetin and vitamin C in Nrf2 dependent oxidative stress production in breast cancer cells. Oncol. Lett. 2017, 13, 1965-1973. [CrossRef]

59. Tsai, P.Y.; Ka, S.M.; Chang, J.M.; Chen, H.C.; Shui, H.A.; Li, C.Y.; Chen, A. Epigallocatechin-3-gallate prevents lupus nephritis development in mice via enhancing the Nrf2 antioxidant pathway and inhibiting NLRP3 inflammasome activation. Free Radic. Biol. Med. 2011, 51, 744-754. [CrossRef]

60. Mohan, T.; Narasimhan, K.K.S.; Ravi, D.B.; Velusamy, P.; Chandrasekar, N.; Chakrapani, L.N.; Periandavan, K. Role of Nrf2 dysfunction in the pathogenesis of diabetic nephropathy: Therapeutic prospect of epigallocatechin-3-gallate. Free Radic. Biol. Med. 2020, 160, 227-238. [CrossRef]

61. Han, J.; Wang, M.; Jing, X.; Shi, H.; Ren, M.; Lou, H. (-)-Epigallocatechin gallate protects against cerebral ischemia-induced oxidative stress via Nrf2/ARE signaling. Neurochem. Res. 2014, 39, 1292-1299. [CrossRef]

62. Kanlaya, R.; Khamchun, S.; Kapincharanon, C.; Thongboonkerd, V. Protective effect of epigallocatechin-3-gallate (EGCG) via Nrf2 pathway against oxalate-induced epithelial mesenchymal transition (EMT) of renal tubular cells. Sci. Rep. 2016, 6, 30233. [CrossRef] [PubMed]

63. Wang, G.; Song, X.; Zhao, L.; Li, Z.; Liu, B. Resveratrol prevents diabetic cardiomyopathy by increasing Nrf2 expression and transcriptional activity. BioMed Res. Int. 2018, 2018, 2150218. [CrossRef] [PubMed]

64. Hui, Y.; Chengyong, T.; Cheng, L.; Haixia, H.; Yuanda, Z.; Weihua, Y. Resveratrol attenuates the cytotoxicity induced by amyloid- $\beta$ 1-42 in PC12 cells by upregulating heme oxygenase-1 via the PI3K/Akt/Nrf2 pathway. Neurochem. Res. 2018, 43, 297-305. [CrossRef] [PubMed]

65. Gaballah, H.H.; Zakaria, S.S.; Elbatsh, M.M.; Tahoon, N.M. Modulatory effects of resveratrol on endoplasmic reticulum stressassociated apoptosis and oxido-inflammatory markers in a rat model of rotenone-induced Parkinson's disease. Chem.-Biol. Interact. 2016, 251, 10-16. [CrossRef]

66. Cheng, L.; Yan, B.; Chen, K.; Jiang, Z.; Zhou, C.; Cao, J.; Sha, H. Resveratrol-induced downregulation of NAF-1 enhances the sensitivity of pancreatic cancer cells to gemcitabine via the ROS/Nrf2 signaling pathways. Oxid. Med. Cell. Longev. 2018, 2018, 9482018. [CrossRef]

67. Kim, E.N.; Lim, J.H.; Kim, M.Y.; Ban, T.H.; Jang, I.A.; Yoon, H.E.; Choi, B.S. Resveratrol, an Nrf2 activator, ameliorates aging-related progressive renal injury. Aging 2018, 10, 83. [CrossRef]

68. Hosseini, H.; Teimouri, M.; Shabani, M.; Koushki, M.; Khorzoughi, R.B.; Namvarjah, F.; Meshkani, R. Resveratrol alleviates non-alcoholic fatty liver disease through epigenetic modification of the Nrf2 signaling pathway. Int. J. Biochem. Cell Biol. 2020, 119, 105667. [CrossRef]

69. Hwang, J.H.; Lim, S.B. Antioxidant and anti-inflammatory activities of broccoli florets in LPS-stimulated RAW 264.7 cells. Prev. Nutr. Food Sci. 2014, 19, 89. [CrossRef]

70. Li, S.; Yang, H.; Chen, X. Protective effects of sulforaphane on diabetic retinopathy: Activation of the Nrf2 pathway and inhibition of NLRP3 inflammasome formation. Exp. Anim. 2019, 68, 221-231. [CrossRef]

71. Zhao, Z.; Liao, G.; Zhou, Q.; Lv, D.; Holthfer, H.; Zou, H. Sulforaphane attenuates contrast-induced nephropathy in rats via Nrf2/HO-1 pathway. Oxid. Med. Cell. Longev. 2016, 2016, 9825623. [CrossRef]

72. Bahn, G.; Park, J.S.; Yun, U.J.; Lee, Y.J.; Choi, Y.; Park, J.S.; Jo, D.G. NRF2/ARE pathway negatively regulates BACE1 expression and ameliorates cognitive deficits in mouse Alzheimer's models. Proc. Natl. Acad. Sci. USA 2019, 116, 12516-12523. [CrossRef]

73. Zhou, Q.; Chen, B.; Wang, X.; Wu, L.; Yang, Y.; Cheng, X.; Cao, P. Sulforaphane protects against rotenone-induced neurotoxicity in vivo: Involvement of the mTOR, Nrf2 and autophagy pathways. Sci. Rep. 2016, 6, 32206. [CrossRef]

74. Xin, Y.; Bai, Y.; Jiang, X.; Zhou, S.; Wang, Y.; Wintergerst, K.A.; Cai, L. Sulforaphane prevents angiotensin II-induced cardiomyopathy by activation of Nrf2 via stimulating the Akt/GSK-3ss/Fyn pathway. Redox Biol. 2018, 15, 405-417. [CrossRef] 
75. Paredes-Gonzalez, X.; Fuentes, F.; Su, Z.Y.; Kong, A.N.T. Apigenin reactivates Nrf2 anti-oxidative stress signaling in mouse skin epidermal JB6 P+ cells through epigenetics modifications. AAPS J. 2014, 16, 727-735. [CrossRef]

76. Yang, Y.; Yang, I.; Cao, M.; Su, Z.Y.; Wu, R.; Guo, Y.; Kong, A.N. Fucoxanthin elicits epigenetic modifications, Nrf2 activation and blocking transformation in mouse skin JB6 P+ cells. AAPS J. 2018, 20, 32. [CrossRef]

77. Li, P.; Bukhari, S.N.A.; Khan, T.; Chitti, R.; Bevoor, D.B.; Hiremath, A.R.; Gubbiyappa, K.S. Apigenin-loaded solid lipid nanoparticle attenuates diabetic nephropathy induced by streptozotocin nicotinamide through Nrf2/HO-1/NF-kB signalling pathway. Int. J. Nanomed. 2020, 15, 9115. [CrossRef]

78. Chen, P.; Huo, X.; Liu, W.; Li, K.; Sun, Z.; Tian, J. Apigenin exhibits anti-inflammatory effects in Lps-stimulated Bv2 microglia through activating Gsk3 $\beta$ /Nrf2 signaling pathway. Immunopharmacol. Immunotoxicol. 2020, 42, 9-16. [CrossRef]

79. Gao, A.M.; Zhang, X.Y.; Ke, Z.P. Apigenin sensitizes BEL-7402/ADM cells to doxorubicin through inhibiting miR-101/Nrf2 pathway. Oncotarget 2017, 8, 82085. [CrossRef]

80. Zhang, J.; Zhao, X.; Zhu, H.; Wang, J.; Ma, J.; Gu, M. Apigenin protects against renal tubular epithelial cell injury and oxidative stress by high glucose via regulation of NF-E2-related factor 2 (Nrf2) pathway. Med. Sci. Monit. 2019, 25, 5280. [CrossRef]

81. Paredes-Gonzalez, X.; Fuentes, F.; Jeffery, S.; Saw, C.L.L.; Shu, L.; Su, Z.Y.; Kong, A.N.T. Induction of NRF2-mediated gene expression by dietary phytochemical flavones apigenin and luteolin. Biopharm. Drug Dispos. 2015, 36, 440-451. [CrossRef]

82. Habtemariam, S. Antioxidant and anti-inflammatory mechanisms of neuroprotection by ursolic acid: Addressing brain injury, cerebral ischemia, cognition deficit, anxiety, and depression. Oxid. Med. Cell. Longev. 2019, 2019, 8512048. [CrossRef] [PubMed]

83. Li, L.; Zhang, X.; Cui, L.; Wang, L.; Liu, H.; Ji, H.; Du, Y. Ursolic acid promotes the neuroprotection by activating Nrf2 pathway after cerebral ischemia in mice. Brain Res. 2013, 1497, 32-39. [CrossRef] [PubMed]

84. Ding, H.; Wang, H.; Zhu, L.; Wei, W. Ursolic acid ameliorates early brain injury after experimental traumatic brain injury in mice by activating the Nrf2 pathway. Neurochem. Res. 2017, 42, 337-346. [CrossRef] [PubMed]

85. Lee, S.I. Protective effects of ursolic acid on osteoblastic differentiation via activation of IER3/Nrf2. J. Dent. Hyg. Sci. 2019, 19, 198-204. [CrossRef]

86. Ma, J.Q.; Ding, J.; Zhang, L.; Liu, C.M. Protective effects of ursolic acid in an experimental model of liver fibrosis through Nrf2/ARE pathway. Clin. Res. Hepatol. Gastroenterol. 2015, 39, 188-197. [CrossRef]

87. Kim, H.; Ramirez, C.N.; Su, Z.Y.; Kong, A.N.T. Epigenetic modifications of triterpenoid ursolic acid in activating Nrf2 and blocking cellular transformation of mouse epidermal cells. J. Nutr. Biochem. 2016, 33, 54-62. [CrossRef]

88. Rajappa, R.; Sireesh, D.; Salai, M.B.; Ramkumar, K.M.; Sarvajayakesavulu, S.; Madhunapantula, S.V. Treatment with naringenin elevates the activity of transcription factor Nrf2 to protect pancreatic $\beta$-cells from streptozotocin-induced diabetes In Vitro and In Vivo. Front. Pharmacol. 2019, 9, 1562. [CrossRef]

89. Lv, Z.; Wu, W.; Ge, S.; Jia, R.; Lin, T.; Yuan, Y.; Zhang, D. Naringin protects against perfluorooctane sulfonate-induced liver injury by modulating NRF2 and NF-кB in mice. Int. Immunopharmacol. 2018, 65, 140-147. [CrossRef]

90. Kapoor, R.; Sirohi, V.K.; Gupta, K.; Dwivedi, A. Naringenin ameliorates progression of endometriosis by modulating Nrf2/Keap1/HO1 axis and inducing apoptosis in rats. J. Nutr. Biochem. 2019, 70, 215-226. [CrossRef]

91. Adil, M.; Kandhare, A.D.; Ghosh, P.; Bodhankar, S.L. Sodium arsenite-induced myocardial bruise in rats: Ameliorative effect of naringin via TGF- $\beta /$ Smad and Nrf/HO pathways. Chem.-Biol. Interact. 2016, 253, 66-77. [CrossRef]

92. Chen, R.J.; Kuo, H.C.; Cheng, L.H.; Lee, Y.H.; Chang, W.T.; Wang, B., Jr.; Cheng, H.C. Apoptotic and nonapoptotic activities of pterostilbene against cancer. Int. J. Mol. Sci. 2018, 19, 287. [CrossRef]

93. Zhou, J.; Ci, X.; Ma, X.; Yu, Q.; Cui, Y.; Zhen, Y.; Li, S. Pterostilbene activates the Nrf2-dependent antioxidant response to ameliorate arsenic-induced intracellular damage and apoptosis in human keratinocytes. Front. Pharmacol. 2019, 10, 497. [CrossRef]

94. Xue, E.X.; Lin, J.P.; Zhang, Y.; Sheng, S.R.; Liu, H.X.; Zhou, Y.L.; Xu, H. Pterostilbene inhibits inflammation and ROS production in chondrocytes by activating Nrf2 pathway. Oncotarget 2017, 8, 41988. [CrossRef]

95. Elango, B.; Dornadula, S.; Paulmurugan, R.; Ramkumar, K.M. Pterostilbene ameliorates streptozotocin-induced diabetes through enhancing antioxidant signaling pathways mediated by Nrf2. Chem. Res. Toxicol. 2016, 29, 47-57. [CrossRef]

96. Zhang, B.; Wang, X.Q.; Chen, H.Y.; Liu, B.H. Involvement of the Nrf2 pathway in the regulation of pterostilbene-induced apoptosis in HeLa cells via ER stress. J. Pharmacol. Sci. 2014, 126, 216-229. [CrossRef]

97. Chatterjee, K.; AlSharif, D.; Mazza, C.; Syar, P.; Al Sharif, M.; Fata, J.E. Resveratrol and pterostilbene exhibit anticancer properties involving the downregulation of HPV oncoprotein E6 in cervical cancer cells. Nutrients 2018, 10, 243. [CrossRef]

98. Gegotek, A.; Jarocka-Karpowicz, I.; Skrzydlewska, E. Cytoprotective effect of ascorbic acid and rutin against oxidative changes in the proteome of skin fibroblasts cultured in a three-dimensional system. Nutrients 2020, 12, 1074. [CrossRef]

99. Singh, S.; Singh, D.K.; Meena, A.; Dubey, V.; Masood, N.; Luqman, S. Rutin protects t butyl hydroperoxide-induced oxidative impairment via modulating the Nrf2 and iNOS activity. Phytomedicine 2019, 55, 92-104. [CrossRef]

100. Mittal, R.; Kumar, A.; Singh, D.P.; Bishnoi, M.; Nag, T.C. Ameliorative potential of rutin in combination with nimesulide in STZ model of diabetic neuropathy: Targeting Nrf2/HO-1/NF-kB and COX signalling pathway. Inflammopharmacology 2018, 26, 755-768. [CrossRef]

101. Oluranti, O.I.; Alabi, B.A.; Michael, O.S.; Ojo, A.O.; Fatokun, B.P. Rutin prevents cardiac oxidative stress and inflammation induced by bisphenol A and dibutyl phthalate exposure via NRF-2/NF-kB pathway. Life Sci. 2021, 284, 119878. [CrossRef] 
102. Li, Y.; Cheng, Z.; Wang, K.; Zhu, X.; Ali, Y.; Shu, W.; Zhou, F. Procyanidin B2 and rutin in Ginkgo biloba extracts protect human retinal pigment epithelial (RPE) cells from oxidative stress by modulating Nrf2 and Erk1/2 signalling. Exp. Eye Res. 2021, 207, 108586. [CrossRef] [PubMed]

103. Thabet, N.M.; Moustafa, E.M. Protective effect of rutin against brain injury induced by acrylamide or gamma radiation: Role of PI3K/AKT/GSK-3ß/NRF-2 signalling pathway. Arch. Physiol. Biochem. 2018, 124, 185-193. [CrossRef] [PubMed]

104. Abou El-ezz, D.; Maher, A.; Sallam, N.; El-Brairy, A.; Kenawy, S. Trans-cinnamaldehyde modulates hippocampal Nrf2 factor and inhibits amyloid beta aggregation in LPS-induced neuroinflammation mouse model. Neurochem. Res. 2018, 43, $2333-2342$. [CrossRef] [PubMed]

105. Wang, P.; Yang, Y.; Wang, D.; Yang, Q.; Wan, J.; Liu, S.; Yang, Y. Cinnamaldehyde ameliorates vascular dysfunction in diabetic mice by activating Nrf2. Am. J. Hypertens. 2020, 33, 610-619. [CrossRef]

106. Ryu, J.S.; Kang, H.Y.; Lee, J.K. Effect of treadmill exercise and trans-cinnamaldehyde against d-galactose-and aluminum chlorideinduced cognitive dysfunction in mice. Brain Sci. 2020, 10, 793. [CrossRef]

107. Uchi, H.; Yasumatsu, M.; Morino-Koga, S.; Mitoma, C.; Furue, M. Inhibition of aryl hydrocarbon receptor signaling and induction of NRF2-mediated antioxidant activity by cinnamaldehyde in human keratinocytes. J. Dermatol. Sci. 2017, 85, 36-43. [CrossRef]

108. Huang, T.C.; Chung, Y.L.; Wu, M.L.; Chuang, S.M. Cinnamaldehyde enhances Nrf2 nuclear translocation to upregulate phase II detoxifying enzyme expression in HepG2 cells. J. Agric. Food Chem. 2011, 59, 5164-5171. [CrossRef]

109. Wang, D.; Hou, J.; Yang, Y.; Zhou, P.; Liu, S.; Wan, J.; Wang, P. Cinnamaldehyde ameliorates high-glucose-induced oxidative stress and cardiomyocyte injury through transient receptor potential ankyrin 1. J. Cardiovasc. Pharmacol. 2019, 74, 30-37. [CrossRef]

110. Shi, Y.; Liang, X.C.; Zhang, H.; Sun, Q.; Wu, Q.L.; Qu, L. Combination of quercetin, cinnamaldehyde and hirudin protects rat dorsal root ganglion neurons against high glucose-induced injury through Nrf-2/HO-1 activation and NF- $\mathrm{B}$ inhibition. Chin. J. Integr. Med. 2017, 23, 663-671. [CrossRef]

111. Wang, F.; Pu, C.; Zhou, P.; Wang, P.; Liang, D.; Wang, Q.; Hu, Y.; Li, B.; Hao, X. Cinnamaldehyde prevents endothelial dysfunction induced by high glucose by activating Nrf2. Cell. Physiol. Biochem. 2015, 36, 315-324. [CrossRef]

112. Lv, H.; Liu, Q.; Wen, Z.; Feng, H.; Deng, X.; Ci, X. Xanthohumol ameliorates lipopolysaccharide (LPS)-induced acute lung injury via induction of AMPK/GSK3 $\beta-N r f 2$ signal axis. Redox Biol. 2017, 12, 311-324. [CrossRef]

113. Krajka-Kuźniak, V.; Cykowiak, M.; Szaefer, H.; Kleszcz, R.; Baer-Dubowska, W. Combination of xanthohumol and phenethyl isothiocyanate inhibits NF- $\mathrm{kB}$ and activates Nrf2 in pancreatic cancer cells. Toxicol. In Vitro 2020, 65, 104799. [CrossRef]

114. Li, F.; Yao, Y.; Huang, H.; Hao, H.; Ying, M. Xanthohumol attenuates cisplatin-induced nephrotoxicity through inhibiting NF- $\mathrm{kB}$ and activating Nrf2 signaling pathways. Int. Immunopharmacol. 2018, 61, 277-282. [CrossRef]

115. Krajka-Kuźniak, V.; Paluszczak, J.; Baer-Dubowska, W. Xanthohumol induces phase II enzymes via Nrf2 in human hepatocytes in vitro. Toxicol. In Vitro 2013, 27, 149-156. [CrossRef]

116. Lee, I.S.; Lim, J.; Gal, J.; Kang, J.C.; Kim, H.J.; Kang, B.Y.; Choi, H.J. Anti-inflammatory activity of xanthohumol involves heme oxygenase-1 induction via NRF2-ARE signaling in microglial BV2 cells. Neurochem. Int. 2011, 58, 153-160. [CrossRef]

117. Yao, J.; Zhang, B.; Ge, C.; Peng, S.; Fang, J. Xanthohumol, a polyphenol chalcone present in hops, activating Nrf2 enzymes to confer protection against oxidative damage in PC12 cells. J. Agric. Food Chem. 2015, 63, 1521-1531. [CrossRef]

118. Egea, J.; Buendia, I.; Parada, E.; Navarro, E.; Rada, P.; Cuadrado, A.; López, M.G.; García, A.G.; León, R. Melatonin-sulforaphane hybrid ITH12674 induces neuroprotection in oxidative stress conditions by a 'drug-prodrug' mechanism of action. Br. J. Pharmacol. 2015, 172, 1807-1821. [CrossRef]

119. Yagishita, Y.; Gatbonton-Schwager, T.N.; McCallum, M.L.; Kensler, T.W. Current landscape of NRF2 biomarkers in clinical trials. Antioxidants 2020, 9, 716. [CrossRef]

120. Tan, X.; Yang, Y.; Xu, J.; Zhang, P.; Deng, R.; Mao, Y.; He, J.; Chen, Y.; Zhang, Y.; Ding, J.; et al. Luteolin exerts neuroprotection via modulation of the p62/Keap1/Nrf2 pathway in intracerebral hemorrhage. Front. Pharmacol. 2020, 10, 1551. [CrossRef]

121. Tidke, P.S.; Patil, C.R. Nrf2 activator corosolic acid meliorates alloxan induced diabetic nephropathy in mice. Asian Pac. J. Trop. Biomed. 2017, 7, 797. [CrossRef]

122. Hong, B.; Su, Z.; Zhang, C.; Yang, Y.; Guo, Y.; Li, W.; Kong, A.N. Reserpine inhibit the JB6 P+ cell transformation through epigenetic reactivation of Nrf2-mediated anti-oxidative stress pathway. AAPS J. 2016, 18, 659-669. [CrossRef] [PubMed]

123. Islam, J.; Shree, A.; Vafa, A.; Afzal, S.M.; Sultana, S. Taxifolin ameliorates Benzo[a]pyrene-induced lung injury possibly via stimulating the Nrf2 signalling pathway. Int. Immunopharmacol. 2021, 96, 107566. [CrossRef] [PubMed]

124. Gill, B.S.; Kumar, S.; Navgeet. Ganoderic acid targeting nuclear factor erythroid 2-related factor 2 in lung cancer. Tumor Biol. 2017, 39, 1010428317695530. [CrossRef] [PubMed]

125. Divya, T.; Dineshbabu, V.; Soumyakrishnan, S.; Sureshkumar, A.; Sudhandiran, G. Celastrol enhances Nrf2 mediated antioxidant enzymes and exhibits anti-fibrotic effect through regulation of collagen production against bleomycin-induced pulmonary fibrosis. Chem.-Biol. Int. 2016, 246, 52-62. [CrossRef]

126. Zhao, X.J.; Yu, H.W.; Yang, Y.Z.; Wu, W.Y.; Chen, T.Y.; Jia, K.K.; Kang, L.L.; Jiao, R.Q.; Kong, L.D. Polydatin prevents fructoseinduced liver inflammation and lipid deposition through increasing miR-200a to regulate Keap1/Nrf2 pathway. Redox Biol. 2018, 18, 124-137. [CrossRef]

127. Li, S.; Li, W.; Wang, C.; Wu, R.; Yin, R.; Kuo, H.C.; Wang, L.; Kong, A.N. Pelargonidin reduces the TPA induced transformation of mouse epidermal cells-potential involvement of Nrf2 promoter demethylation. Chem.-Biol. Interact. 2019, 309, 108701. [CrossRef] 
128. Kuo, H.D.; Wu, R.; Li, S.; Yang, A.Y.; Kong, A.N. Anthocyanin delphinidin prevents neoplastic transformation of mouse skin JB6 P+ cells: Epigenetic reactivation of Nrf2-ARE pathway. AAPS J. 2019, 21, 83. [CrossRef]

129. Okada, K.; Shoda, J.; Taguchi, K.; Maher, J.M.; Ishizaki, K.; Inoue, Y.; Yamamoto, M. Ursodeoxycholic acid stimulates Nrf2mediated hepatocellular transport, detoxification, and antioxidative stress systems in mice. Am. J. Physiol. Gastrointest. Liver Physiol. 2008, 295, G735-G747. [CrossRef]

130. Lee, B.H.; Hsu, W.H.; Hsu, Y.W.; Pan, T.M. Dimerumic acid attenuates receptor for advanced glycation end products signal to inhibit inflammation and diabetes mediated by Nrf2 activation and promotes methylglyoxal metabolism into d-lactic acid. Free Radic. Biol. Med. 2013, 60, 7-16. [CrossRef]

131. Li, Y.; Feng, Y.F.; Liu, X.T.; Li, Y.C.; Zhu, H.M.; Sun, M.R.; Yang, H. Songorine promotes cardiac mitochondrial biogenesis via Nrf2 induction during sepsis. Redox Biol. 2021, 38, 101771. [CrossRef]

132. Ohnuma, T.; Sakamoto, K.; Shinoda, A.; Takagi, C.; Ohno, S.; Nishiyama, T.; Hiratsuka, A. Procyanidins from Cinnamomi cortex promote proteasome-independent degradation of nuclear Nrf2 through phosphorylation of insulin-like growth factor-1 receptor in A549 cells. Arch. Biochem. Biophys. 2017, 635, 66-73. [CrossRef]

133. Davies, T.G.; Wixted, W.E.; Coyle, J.E.; Griffiths-Jones, C.; Hearn, K.; McMenamin, R.; Kerns, J.K. Monoacidic inhibitors of the Kelch-like ECH-associated protein 1: Nuclear factor erythroid 2-related factor 2 (KEAP1: NRF2) protein-protein interaction with high cell potency identified by fragment-based discovery. J. Med. Chem. 2016, 59, 3991-4006. [CrossRef]

134. Lu, M.C.; Jiao, Q.; Liu, T.; Tan, S.J.; Zhou, H.S.; You, Q.D.; Jiang, Z.Y. Discovery of a head-to-tail cyclic peptide as the Keap1-Nrf2 protein-protein interaction inhibitor with high cell potency. Eur. J. Med. Chem. 2018, 143, 1578-1589. [CrossRef]

135. Hassanein, E.H.; Sayed, A.M.; Hussein, O.E.; Mahmoud, A.M. Coumarins as modulators of the Keap1/Nrf2/ARE signaling pathway. Oxid. Med. Cell. Longev. 2020, 2020, 1675957. [CrossRef]

136. Choi, J.W.; Kim, G.J.; Kim, H.J.; Nam, J.W.; Kim, J.; Chin, J.; Park, K.D. Identification and evaluation of a napyradiomycin as a potent Nrf2 activator: Anti-oxidative and anti-inflammatory activities. Bioorg. Chem. 2020, 105, 104434. [CrossRef]

137. Singh, A.; Venkannagari, S.; Oh, K.H.; Zhang, Y.Q.; Rohde, J.M.; Liu, L.; Biswal, S. Small molecule inhibitor of NRF2 selectively intervenes therapeutic resistance in KEAP1-deficient NSCLC tumors. ACS Chem. Biol. 2016, 11, 3214-3225. [CrossRef]

138. Shin, D.; Kim, E.H.; Lee, J.; Roh, J.L. Nrf2 inhibition reverses resistance to GPX4 inhibitor-induced ferroptosis in head and neck cancer. Free Radic. Biol. Med. 2018, 129, 454-462. [CrossRef]

139. Zhou, J.W.; Wang, M.; Sun, N.X.; Qing, Y.; Yin, T.F.; Li, C.; Wu, D. Sulforaphane induced epigenetic regulation of Nrf2 expression by DNA methyltransferase in human Caco 2 cells. Oncol. Lett. 2019, 18, 2639-2647. [CrossRef]

140. Su, Z.Y.; Zhang, C.; Lee, J.H.; Shu, L.; Wu, T.Y.; Khor, T.O.; Kong, A.N.T. Requirement and epigenetics reprogramming of Nrf2 in suppression of tumor promoter TPA-induced mouse skin cell transformation by sulforaphane. Cancer Prev. Res. 2014, 7, 319-329. [CrossRef]

141. Khor, T.O.; Huang, Y.; Wu, T.Y.; Shu, L.; Lee, J.; Kong, A.N.T. Pharmacodynamics of curcumin as DNA hypomethylation agent in restoring the expression of Nrf2 via promoter CpGs demethylation. Biochem. Pharmacol. 2011, 82, 1073-1078. [CrossRef]

142. Singh, B.; Shoulson, R.; Chatterjee, A.; Ronghe, A.; Bhat, N.K.; Dim, D.C.; Bhat, H.K. Resveratrol inhibits estrogen-induced breast carcinogenesis through induction of NRF2-mediated protective pathways. Carcinogenesis 2014, 35, 1872-1880. [CrossRef] [PubMed]

143. Huang, Y.; Khor, T.O.; Shu, L.; Saw, C.L.L.; Wu, T.Y.; Suh, N.; Kong, A.N.T. A $\gamma$-tocopherol-rich mixture of tocopherols maintains Nrf2 expression in prostate tumors of TRAMP mice via epigenetic inhibition of CpG methylation. J. Nutr. 2012, 142, 818-823. [CrossRef] [PubMed]

144. Kang, K.A.; Piao, M.J.; Hyun, Y.J.; Zhen, A.X.; Cho, S.J.; Ahn, M.J.; Hyun, J.W. Luteolin promotes apoptotic cell death via upregulation of Nrf2 expression by DNA demethylase and the interaction of Nrf2 with p53 in human colon cancer cells. Exp. Mol. Med. 2019, 51, 1-14. [CrossRef] [PubMed]

145. Su, Z.Y.; Khor, T.O.; Shu, L.; Lee, J.H.; Saw, C.L.L.; Wu, T.Y.; Kong, A.N.T. Epigenetic reactivation of Nrf2 in murine prostate cancer TRAMP C1 cells by natural phytochemicals Z-ligustilide and Radix angelica sinensis via promoter CpG demethylation. Chem. Res. Toxicol. 2013, 26, 477-485. [CrossRef]

146. Wang, S.W.; Sheng, H.; Bai, Y.F.; Weng, Y.Y.; Fan, X.Y.; Zheng, F.; Zhang, F. Inhibition of histone acetyltransferase by naringenin and hesperetin suppresses Txnip expression and protects pancreatic $\beta$ cells in diabetic mice. Phytomedicine 2021, 88, 153454. [CrossRef]

147. Qian, Y.Y.; Liu, Z.S.; Yan, H.J.; Yuan, Y.F.; Levenson, A.S.; Li, K. Pterostilbene inhibits MTA1/HDAC1 complex leading to PTEN acetylation in hepatocellular carcinoma. Biomed. Pharmacother. 2018, 101, 852-859. [CrossRef]

148. Lee, J.; Song, J.H.; Chung, M.Y.; Lee, J.H.; Nam, T.G.; Park, J.H.; Choi, H.K. 3, 4-dihydroxytoluene, a metabolite of rutin, suppresses the progression of nonalcoholic fatty liver disease in mice by inhibiting p300 histone acetyltransferase activity. Acta Pharmacol. Sin. 2020, 42, 1449-1460. [CrossRef]

149. Kim, T.W. Cinnamaldehyde induces autophagy-mediated cell death through ER stress and epigenetic modification in gastric cancer cells. Acta Pharmacol. Sin. 2021, 1-12. [CrossRef]

150. Liu, X.; Song, Z.; Bai, J.; Nauwynck, H.; Zhao, Y.; Jiang, P. Xanthohumol inhibits PRRSV proliferation and alleviates oxidative stress induced by PRRSV via the Nrf2-HMOX1 axis. Vet. Res. 2019, 50, 61. [CrossRef] 
151. Xu, Y.; Yuan, H.; Luo, Y.; Zhao, Y.J.; Xiao, J.H. Ganoderic acid D protects human amniotic mesenchymal stem cells against oxidative stress-induced senescence through the PERK/NRF2 signaling pathway. Oxid. Med. Cell. Longev. 2020, 2020, 8291413. [CrossRef]

152. Li, W.; Suwanwela, N.C.; Patumraj, S. Curcumin by down-regulating NF-kB and elevating Nrf2, reduces brain edema and neurological dysfunction after cerebral I/R. Microvasc. Res. 2016, 106, 117-127. [CrossRef]

153. Karthi, N.; Karthiga, A.; Kalaiyarasu, T.; Stalin, A.; Manju, V.; Singh, S.K.; Lee, S.M. Exploration of cell cycle regulation and modulation of the DNA methylation mechanism of pelargonidin: Insights from the molecular modeling approach. Comput. Biol. Chem. 2017, 70, 175-185. [CrossRef]

154. Zuo, Q.; Wu, R.; Xiao, X.; Yang, C.; Yang, Y.; Wang, C.; Kong, A.N. The dietary flavone luteolin epigenetically activates the Nrf2 pathway and blocks cell transformation in human colorectal cancer HCT116 cells. J. Cell. Biochem. 2018, 119, 9573-9582. [CrossRef]

155. Yang, M.; Jiang, Z.H.; Li, C.G.; Zhu, Y.J.; Li, Z.; Tang, Y.Z.; Ni, C.L. Apigenin prevents metabolic syndrome in high-fructose diet-fed mice by Keap1-Nrf2 pathway. Biomed. Pharmacother. 2018, 105, 1283-1290. [CrossRef]

156. Hudlikar, R.R.; Sargsyan, D.; Wu, R.; Su, S.; Zheng, M.; Kong, A.N. Triterpenoid corosolic acid modulates global CpG methylation and transcriptome of tumor promotor TPA induced mouse epidermal JB6 P+ cells. Chem.-Biol. Interact. 2020, $321,109025$. [CrossRef] 